University of Nebraska - Lincoln

DigitalCommons@University of Nebraska - Lincoln

Papers in the Earth and Atmospheric Sciences

Earth and Atmospheric Sciences, Department

2005

\title{
New Stratigraphic Subdivision, Depositional Environment, and Age Estimate for the Upper Cretaceous Djadokhta Formation, Southern Ulan Nur Basin, Mongolia
}

\author{
Demberelyin Dashzeveg \\ Geological Institute of the Mongolian Academy of Sciences, sbayar68@yahoo.com \\ Lowell Dingus \\ American Museum of Natural History, Idingus@earthlink.net \\ David B. Loope \\ University of Nebraska, Lincoln, dloope1@unl.edu \\ Carl C. Swisher III \\ Rutgers University \\ Togtokh Dulam \\ Mongolian Geological Survey \\ See next page for additional authors \\ Follow this and additional works at: https://digitalcommons.unl.edu/geosciencefacpub \\ Part of the Earth Sciences Commons
}

Dashzeveg, Demberelyin; Dingus, Lowell; Loope, David B.; Swisher, Carl C. III; Dulam, Togtokh; and Sweeney, Mark R., "New Stratigraphic Subdivision, Depositional Environment, and Age Estimate for the Upper Cretaceous Djadokhta Formation, Southern Ulan Nur Basin, Mongolia" (2005). Papers in the Earth and Atmospheric Sciences. 209.

https://digitalcommons.unl.edu/geosciencefacpub/209

This Article is brought to you for free and open access by the Earth and Atmospheric Sciences, Department of at DigitalCommons@University of Nebraska - Lincoln. It has been accepted for inclusion in Papers in the Earth and Atmospheric Sciences by an authorized administrator of DigitalCommons@University of Nebraska - Lincoln. 
Authors

Demberelyin Dashzeveg, Lowell Dingus, David B. Loope, Carl C. Swisher III, Togtokh Dulam, and Mark R. Sweeney 


\title{
Novitates
AMERICAN MUSEM
}

PUBLISHED BY THE AMERICAN MUSEUM OF NATURAL HISTORY CENTRAL PARK WEST AT 79TH STREET, NEW YORK, NY 10024

Number 3498, 31 pp., 14 figures, 3 maps, 2 tables November 29, 2005

\section{New Stratigraphic Subdivision, Depositional Environment, and Age Estimate for the Upper Cretaceous Djadokhta Formation, Southern Ulan Nur Basin, Mongolia}

\author{
DEMBERELYIN DASHZEVEG,${ }^{1}$ LOWELL DINGUS, ${ }^{2}$ DAVID B. LOOPE,${ }^{3}$ \\ CARL C. SWISHER III, ${ }^{4}$ TOGTOKH DULAM, ${ }^{5}$ AND MARK R. SWEENEY ${ }^{6}$
}

\begin{abstract}
Studies of key and newly discovered sections of the Upper Cretaceous Djadokhta Formation along the southern margin of the Ulan Nur Basin allow a new subdivision based on lithology. The formation and its members were mapped at both Bayn Dzak, an area that includes the Flaming Cliffs, and Tugrugyin Shireh, an area about $50 \mathrm{~km}$ to the northwest of Bayn Dzak. Stratigraphic sections at both localities were remeasured. The considerably enlarged formation comprises a lower Bayn Dzak Member, dominated by moderate reddish orange sands with subordinate mudstone units, and an upper Tugrugyin Member, composed of pale orange to light gray sands. Investigations of key sections at Tsonzh and Alag Teer demonstrate the presence of transitional mudstone lenses between these members within the Djadokhta Formation. Two distinct, sandy, sedimentologic facies are recognized in both members. Crossbedded intervals, occasionally exhibiting wind-ripple cross lamination, document the presence
\end{abstract}

\footnotetext{
${ }^{1}$ The Geological Institute of the Mongolian Academy of Sciences, Peace Street 63, Ulaanbaatar-51, Mongolia (sbayar68@yahoo.com).

${ }^{2}$ Division of Paleontology, American Museum of Natural History (ldingus@earthlink.net).

${ }^{3}$ Department of Geosciences, University of Nebraska, Lincoln, Nebraska 68588-0340 (dloope1@ unlnotes.unl.edu).

${ }^{4}$ Department of Geology, Rutgers University, 610 Taylor Road, Piscataway, New Jersey 08854 (cswish@ rci.rutgers.edu).

${ }^{5}$ Mineral Resources Authority of Mongolia, Mongolian Geological Survey, "Gurvan Talst” Company Ltd., Ulaanbaatar, Mongolia.

${ }^{6}$ Desert Research Institute, University of Nevada, 2215 Raggio Parkway, Reno, NV 89512 (mark.sweeney@dri.edu).
} 
of a Cretaceous dunefield in the Ulan Nur Basin. Structureless intervals are interpreted to represent wet sandy fluvial deposits and debris flows that moved down the dune faces. In the Bayn Dzak Member, lenses of brownish mudstone are interpreted to represent interdune deposition in shallow ponds by fluvial action. Fluvial action is also represented in the Bayn Dzak Member by beds of caliche, which contain conglomerate at the base but fine upward into limestone.

The vertebrate fauna from the Djadokhta Formation is summarized. Although the Bayn Dzak fauna lived somewhat earlier than that from Tugrugyin Shireh based on the superposition of the members, it is not clear how much earlier. The fauna from the Djadokhta Formation has previously been assigned ages from Cenomanian to earliest Maastrichtian. New magnetostratigraphic data document a sequence of normal and reversed magnetozones through the Bayn Dzak Member up into the basal Tugrugyin Member. The presence of reversed magnetozones establishes that the sediments containing the faunas were probably deposited after C34n. The quick stratigraphic succession of normal and reversed magnetozones suggests, but does not clearly establish, that the sediments may have been deposited during the rapid sequence of polarity changes in the late part of the Campanian between about 75 to $71 \mathrm{Ma}$.

\section{INTRODUCTION}

In 1922-1923 and 1925 the Central Asiatic Expedition (CAE) of the American Museum of Natural History worked in the Ulan Nur (= Ulaan Nuur of Benton, 2000) Basin (Berkey and Morris, 1927; Andrews, 1932; Morris, 1936). Bayn Dzak (= Bayan Zag of Benton, 2000) was the main locality to be studied by the CAE under the name of Shabarakh Usu (= Flaming Cliffs). There, Americans found dinosaur eggs and nests, Cretaceous mammals, complete skeletons of Protoceratops, and three forms of theropod dinosaurs, including Velociraptor, Saurornithoides, and Oviraptor (Osborn, 1924). Berkey and Morris first referred the recognized Djadokhta Formation to the Lower Cretaceous and then to the lower part of the Upper Cretaceous. Gradziński et al. (1977) provided the lists of fossils known at that time from the Djadokhta, younger Barun Goyot (= Baruungoyot of Benton, 2000), and Nemegt Formations, and estimated the age of the Djadokhta Formation as ?upper Santonian and/or ?lower Campanian.

In 1946 the Bayn Dzak locality was reinvestigated by the Mongolian Paleontological Expedition (MPE) of the Academy of Sciences of the USSR, which was headed by Efremov $(1949,1954)$. The investigations yielded less significant results, including a complete postcranial skeleton of the armored dinosaur Pinacosaurus grangeri Gilmore (= Syrmosaurus viminicaudus) (Maleev 1952, 1954). Additional results regarding this spec- imen were discussed by Maryańska (1971), in a paper not associated with the MPE.

In 1963-1971 the Polish-Mongolian Paleontological Expedition (PMPE) searched for Cretaceous mammals and dinosaurs at Bayn Dzak. The main result was the discovery of abundant fossils of multituberculates, eutherian and deltatheroidan mammals in the locality's concretionary sandstones (KielanJaworowska, 1969, 1970; Kielan-Jaworowska and Dovchin, 1969; Kielan-Jaworowska and Barsbold, 1972), as well as numerous lizards (see Alifanov, 2000, for review), and a peculiar long-necked crocodile (Osmólska, 1972).

In 1971 a spectacular specimen termed the "fighting dinosaurs" was found by PMPE at Tugrugyin Shireh (= Tögrögiin Shiree of Benton, 2000). These articulated and associated skeletons of Velociraptor and Protoceratops are discussed by Kielan-Jaworowska and Barsbold (1972) and Osmólska (1993). Another interesting finding of the PMPE at Tugrugyin Shireh was skeletons of Protoceratops andrewsi preserved in a vertical position (Jerzykiewicz et al., 1993).

In 1969-1970 the joint Soviet-Mongolian Paleontological Expedition (SMPE) found skeletons of Protoceratops andrewsi and other fossils at Tugrugyin Shireh about 50 $\mathrm{km}$ northwest of Bayn Dzak. Other results of both the SMPE and its successor, the Russian-Mongolian Expeditions are reviewed by Kurochkin and Barsbold (2000).

From 1992 to the present, the Japan-Mongolia Joint Paleontological Expedition 
(JMJPE) has conducted extensive field seasons throughout the Gobi Desert. A recent account of their activities at both Bayn Dzak and Tugrugyin Shireh is presented by Ishii et al. $(2000,2004)$.

In 1991 the Mongolian Academy of Science-American Museum of Natural History Expedition (MAE) began field investigations based on the Agreement on Scientific Cooperation between those two institutions. In 1991-1992, 1994-1996, and 1998 the MAE visited Bayn Dzak and Tugrugyin Shireh. Significant remains of multituberculates and placental mammals were collected. Many specimens in these collections are now being studied. The MAE investigated all previously studied reference sections and described some new key sections from the Djadokhta Formation, allowing a stratigraphic reassessment of this formation throughout the region. Major lithostratigraphic units and sedimentary facies were mapped, and samples for paleomagnetic analysis were collected from different sites and stratigraphic levels. It is noteworthy that despite extensive descriptions of fossil faunas, no regional stratigraphic scheme for correlating the sections and faunas of these Upper Cretaceous deposits in the Djadokhta Formation has been previously proposed. Investigations of the MAE resulted in a refined subdivision of these deposits in the Ulan Nur Basin that allow the stratigraphic relationship between the deposits at Bayn Dzak and Tugrugyin Shireh to be clarified.

\section{SUBDIVISION OF THE UPPER CRETACEOUS DJADOKHTA FORMATION ALONG THE SOUTHERN BORDER OF THE ULAN NUR BASIN, MONGOLIA}

The Djadokhta Formation is represented by moderate reddish orange and pale orange to light gray, medium- to fine-grained sands and sandstones containing subordinate layers of calcareous concretions and orangish brown silty clay. Total exposed thickness of the formation in the Ulan Nur Basin, a postOligocene tectonic depression (Gradziński et al., 1977) is at least $80 \mathrm{~m}$. Highly fossiliferous, the formation can be divided into two members and correlated to analogous depos- its in adjacent regions. The Djadokhta Formation was initially considered to consist only of reddish orange sandstones at Bayn Dzak. This understanding of its stratigraphic extent and lithologic composition held until recently. Discussions of earlier geologic studies in the region include Gradziński et al. (1969, 1977); Kielan-Jaworowska and Dovchin (1969); Gradziński (1970); Gradziński and Jerzykiewicz (1972); Kielan-Jaworowska and Barsbold (1972); Gradziński and Jerzykiewicz (1974); Osmólska (1980); Jerzykiewicz and Russell (1991); Jerzykiewicz et al. (1993); Kielan-Jaworowska et al. (2003); Benton et al. (2000) and chapters therein, including Benton (2000), Kurochkin and Barsbold (2000), Shuvalov (2000), and Jerzykiewicz (2000). Based on new stratigraphic and paleontologic data, however, the Upper Cretaceous Djadokhta Formation of the Ulan Nur Basin can now be subdivided into a lower Bayn Dzak Member and an upper Turgrugyin Member.

\section{THE BAYN DZAK MEMBER}

The Bayn Dzak Member forms a range of moderate reddish orange sandstones and moderate reddish brown mudstones, which occur only along the southern edge of the basin. The most complete and fossiliferous exposures of the member are exposed at Bayn Dzak, including the famous outcrops of the Flaming Cliffs (fig. 1; Berkey and Morris, 1927; Andrews, 1932; Gradziński et al., 1969, 1977; Lefeld, 1971; Novacek et al., 1994). The type section was recorded at the Flaming Cliffs (Gradziński et al., 1969: fig. 30). This section consists of strongly dissected scarps composed predominantly of moderate reddish orange sandstone. The central scarps form a large remnant named the Flaming Cliffs by the CAE, in which the combined strata rise more than $30 \mathrm{~m}$ above the floor of the local basin. The Bayn Dzak Member as exposed in the Flaming Cliffs section contains the following lithologic units (see fig. 2):

1. Well-sorted, unbedded, medium-grained sand of moderate reddish orange color $(\mathrm{Ks})$. This unit varies between $2 \mathrm{~m}$ and $14 \mathrm{~m}$ in thickness along the main escarpment and contains the greatest number of dinosaur fos- 


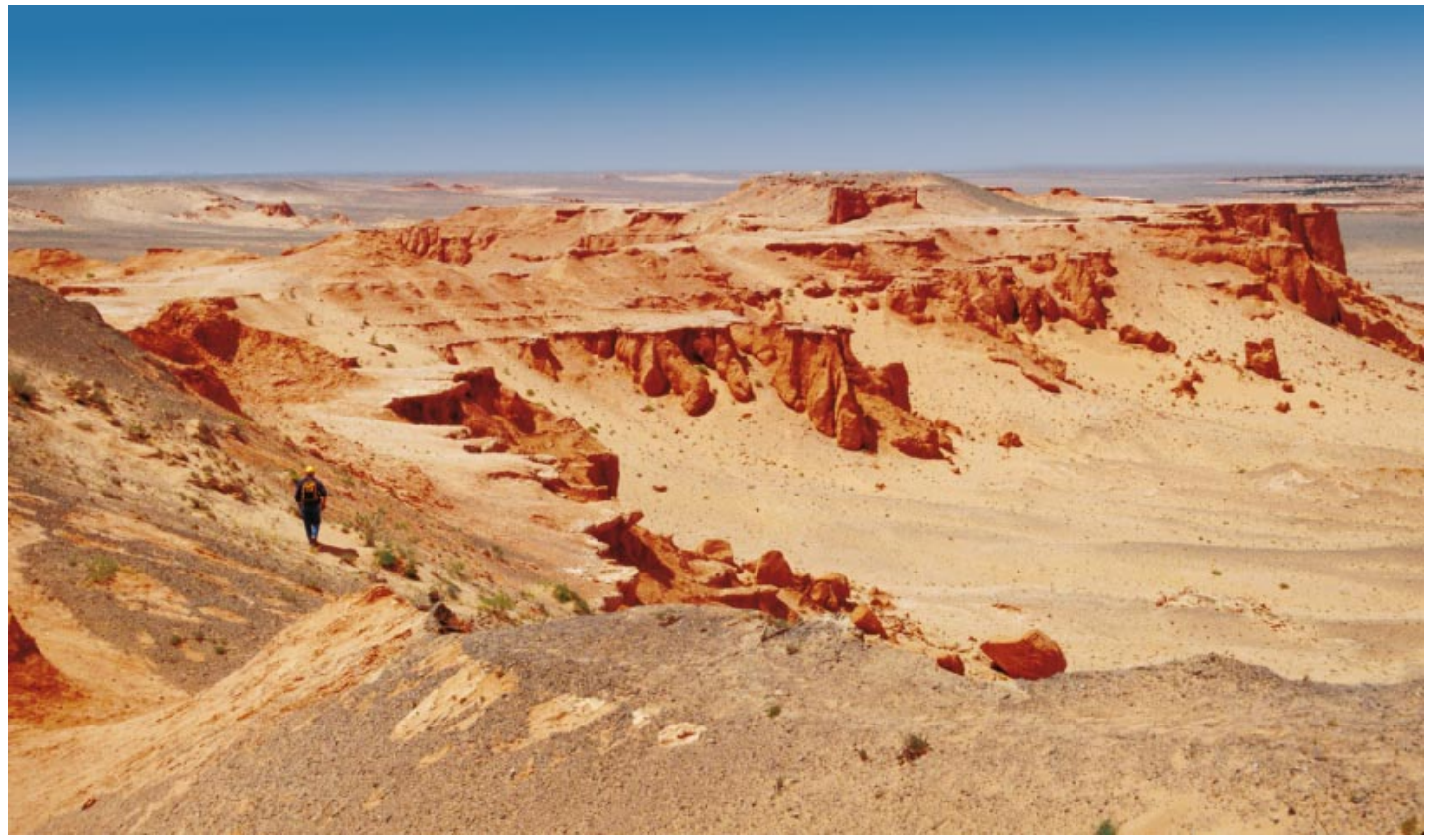

Fig. 1. View looking west at the eastern face of the main escarpment of the Flaming Cliffs. The person in the left-center foreground is walking just above the prominent Kcal Unit 4 in the Flaming Cliffs section (fig. 2), which overlies the prominent cliff-forming sands of Unit 3.

sils. Skeletons and skeletal fragments of Protoceratops andrewsi, Pinacosaurus grangeri, Velociraptor mongoliensis, Oviraptor philoceratops, and Saurornithoides mongoliensis were collected from this unit. Our investigation was unable to distinguish two, lithologically distinct, structureless sandstone units bearing calcareous nodules at the base of the Flaming Cliffs section. Thus, Unit 1 of this study combines Beds 1 and 2 of Gradziński et al. (1969).

2. Well-cemented, reddish brown sandstones sometimes exhibiting large-scale crossbeds (Kcon), 5-7 m thick (fig. 3). Field investigations of the MAE in 1994-1995 documented that concretions in these deposits contain abundant remains of mammals, lizards, and other vertebrates. In 1964 the PMPE found a multituberculate cranium in situ (Gradziński et al., 1969, 1977). The remains of Cretaceous mammals and other small vertebrates are often derived from these sandstones at the base of the Flaming Cliffs scarp. Thus, Unit 2 of this study, which contains mammalian remains, is located above the dinosaur-bearing Unit 1 at the base of the Flaming Cliffs sequence, and Unit 2 of this study is equivalent to Bed 3 of Gradziński et al. (1969).

3. Unbedded, moderate reddish orange sands with irregular sandstone concretions and calcareous nodules (Ks). This unit comprises about $12 \mathrm{~m}$ of structureless, cliff-forming, generally poorly consolidated sandstone (fig. 4). It is equivalent to Unit 4 of Gradziński et al. (1969).

4. Grayish white conglomerates with small rounded calcareous nodules and pebbles of crystalline rock at the base (fig. 5), fining upward into calcareous caliche at the top of the unit (Kcal). Unit 4 of this study equals Bed 5 of Gradziński et al., 1969).

5. Unconsolidated moderate reddish orange sands with small sandy irregular concretions (= Bed 6 of Gradziński et al., 1969). This unit was mapped as part of the Kcal complex on the Facies Map (map 2, pp. 12-13).

6. Light gray calcareous caliche conglomerate with caliche pebbles at base (fig. 5) (= Bed 7 of Gradziński et al., 1969). This unit 


\section{FLAMING CLIFFS}

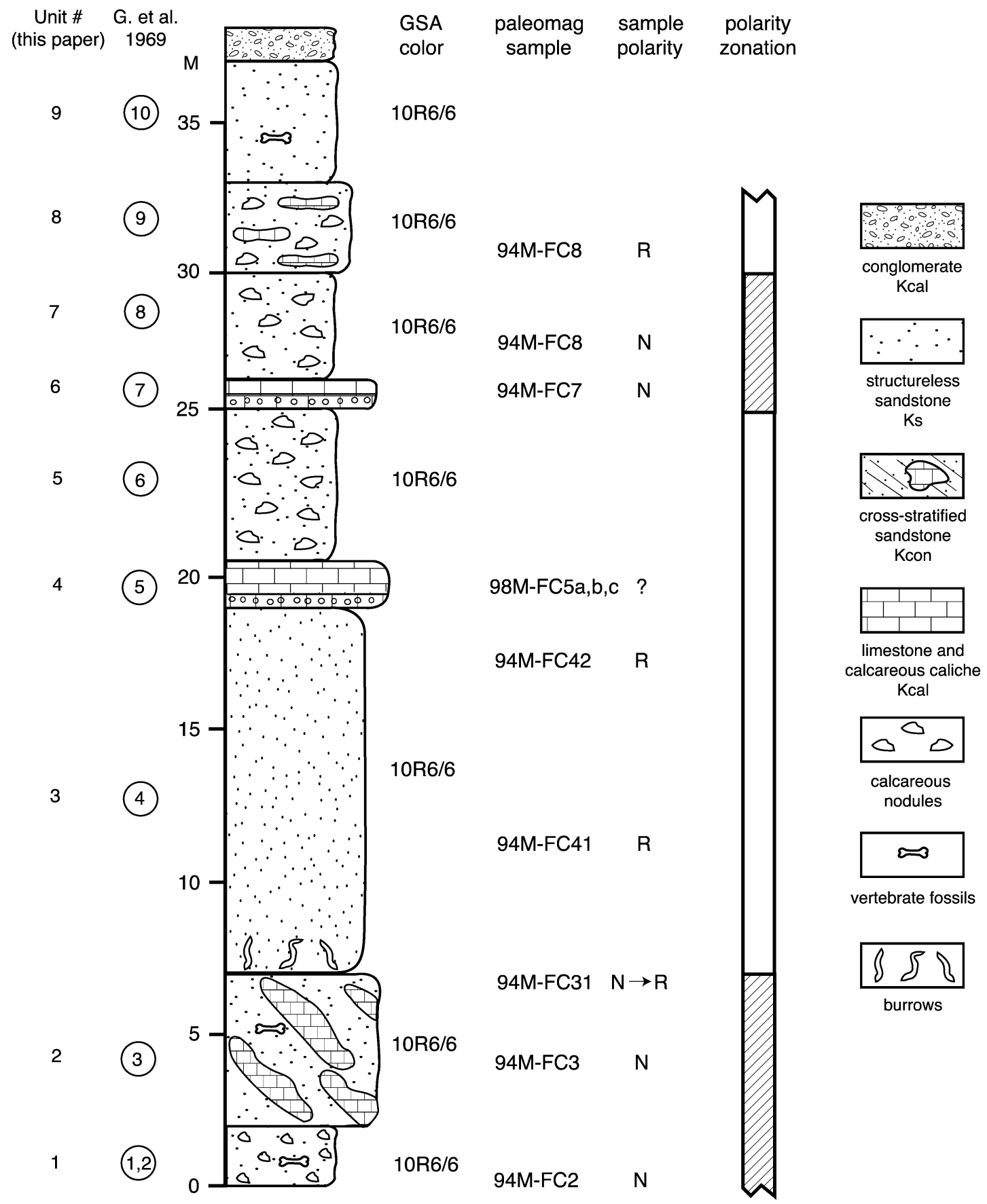

Fig. 2. Stratigraphic section at the Flaming Cliffs proper. Unit designations for this paper are at the far left. Unit designations for Gradziński et al. (1969) are to the immediate right. Colors are based on the GSA color chart. The position of the paleomagnetic samples is to the right of the section. The polarity of the samples is to the right of the sample number. The polarity zonation is at the far right. 


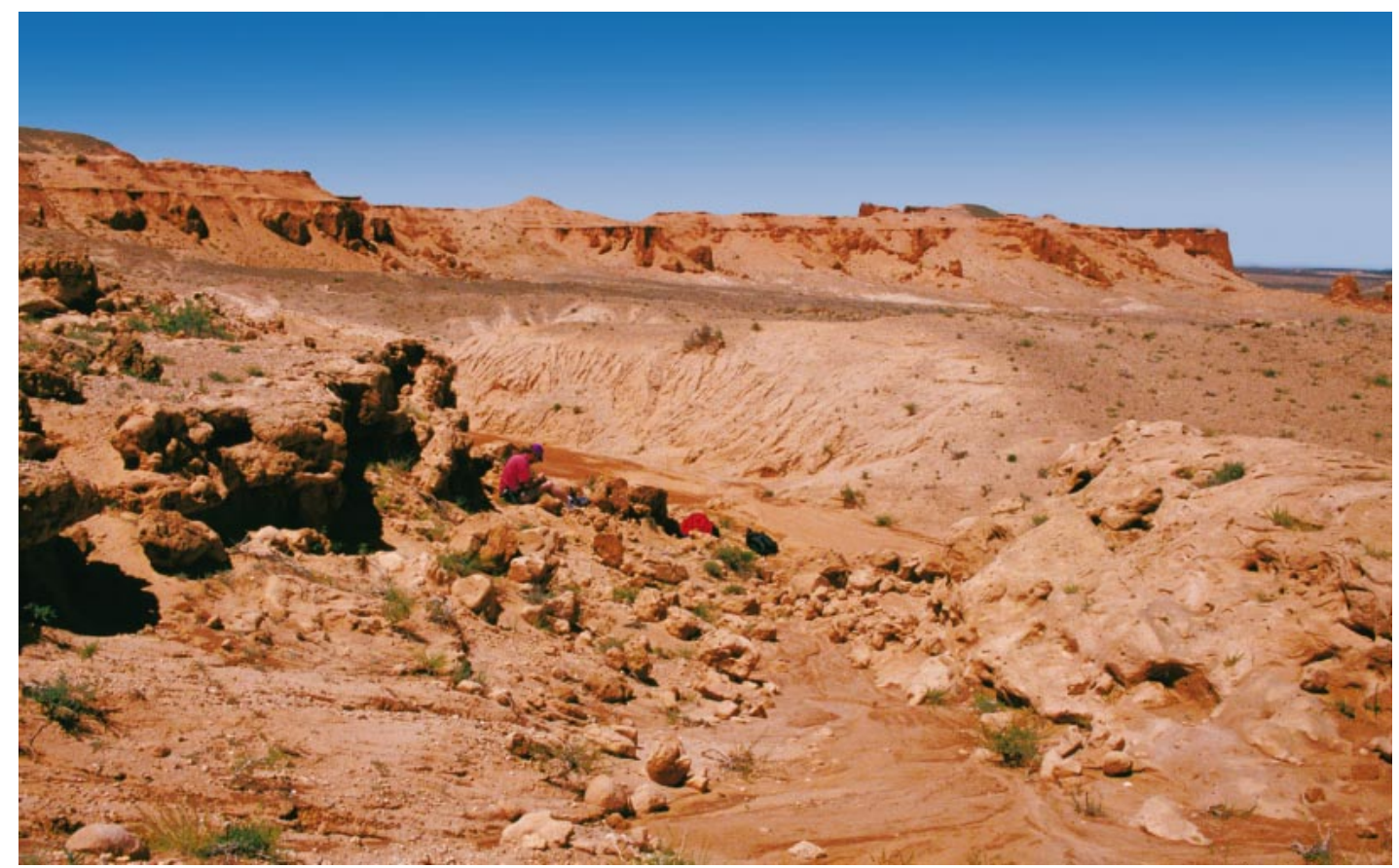

Fig. 3. Resistant, reddish brown, concretionary sandstone of Unit 2 (Kcon) exposed to the east and near the base of the main escarpment of the Flaming Cliffs.

is mapped as part of the Kcal complex on map 2, pp. 12-13.

7. Moderate reddish orange, structureless sandstone with occasional irregular, rounded concretions ( $=$ Bed 8 of Gradziński et al., 1969). Thickness is $4 \mathrm{~m}$. This unit is mapped as part of the Kcal complex on map 2, pp. $12-13$.

8. Moderate reddish orange sands with rounded sandstone concretions (= Bed 9 of Gradziński et al., 1969). This unit is mapped as part of the Kcal complex on map 2, pp. $12-13$.

9. Moderate reddish orange cemented sands and sandstone (= Bed 10 of Gradziński et al., 1969). In 1994 the MAE collected a skull of the lizard Carusia intermedia also known from the Cretaceous deposits of Khermin Tsav and Ukhaa Tolgod from this unit, as well as Chelonia remains from this locality. This unit is mapped as part of the Kcal complex on map 2, pp. 12-13.

The upper part of the Bayn Dzak Member at the Flaming Cliffs has been eroded. Quaternary pediment sits atop the described section. The PMPE studied and described the uppermost bed of the moderate reddish brown sequence of the Bayn Dzak Member located to the northwest of the Flaming Cliffs (Lefeld, 1971). See the subsequent description of Khren Tsav for details.

\section{GEOLOGIC MAP OF MAJOR LITHOSTRATIGRAPHIC UNITS AT BAYN DZAK}

Exposures of the Upper Cretaceous Djadokhta Formation are intermixed with those of Quaternary sediments across the northern two-thirds of the mapped region on map 1. The Djadokhta Formation represents the oldest rocks exposed in the mapped area. The Flaming Cliffs exposures of the Djadokhta Formation stand out in the northern quarter of the map as a southeast to northwest trending arc. To the south of the southeastern end of the Flaming Cliffs exposures, the Djadokhta Formation crops out at lower elevations near the bottom of the major drainage called Khatato Gol.

Overlying the Djadokhta Formation are sediments of the Paleocene Hashaat suite. 


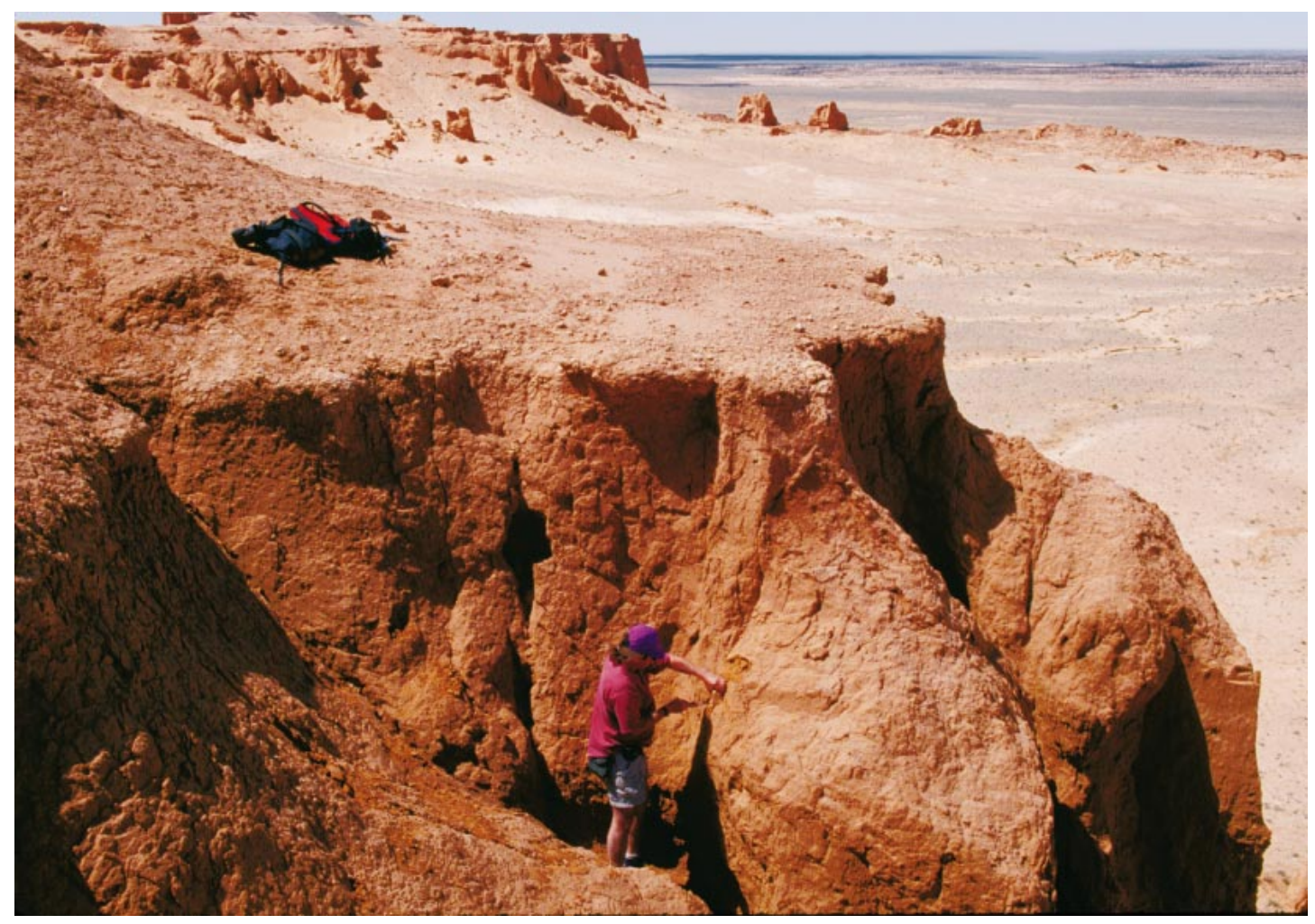

Fig. 4. Structureless, cliff-forming sandstone (Unit 3) exposed near the east end of the main escarpment of the Flaming Cliffs. Unit 4 can be seen on top of Unit 3.

These exposures rim those of the Djadokhta Formation in the central region of the mapped area on either side of the Khatato Gol.

Overlying the Hashaat suite are Eocene sediments. These are primarily exposed in the southernmost part of the mapped area, rimming the exposures of the Hashaat suite.

The youngest rocks in the mapped area consist of Quaternary alluvium, colluvium, and eolian sands. These are distributed throughout the mapped area.

\section{FACIES MAP OF BAYN DZAK MEMBER AT BAYN DZAK WITH ENVIRONMENTAL INTERPRETATIONS}

The Bayn Dzak Member at Bayn Dzak is composed of four different lithologic facies, shown on map 2, pp. 12-13. Very similar facies were recognized by Jerzykiewicz et al. (1993) and Eberth (1993) in exposures of the Djadokhta Formation at Bayan Mandahu in northern China. Topographic and distance references are based on the topographic map for the Bayn Dzak area constructed by L. B. Roberts, F. B. Butler, and H. O. Robinson in 1925, which was printed in Gradziński et al. (1969: fig. 29). The four lithologic facies include the following:

1. Structureless sands, usually poorly consolidated and commonly containing irregular calcareous nodules, dominate Units 1 and 3 of this study. In situ dinosaur nests and skeletal remains are common in Unit 1. Calcareous nodules occurring as float on this unit occasionally contain fossils of mammals and lizards. Trace fossils, often mud filled, are common in unit 3. The fossils are identified as Ophiomorpha by Loope and Dingus (1999). These structureless sands are interpreted to represent fluvial deposits and are mapped as Ks. Other units of structureless sand are similar to the structureless sands described from Ukhaa Tolgod by Loope et al. 


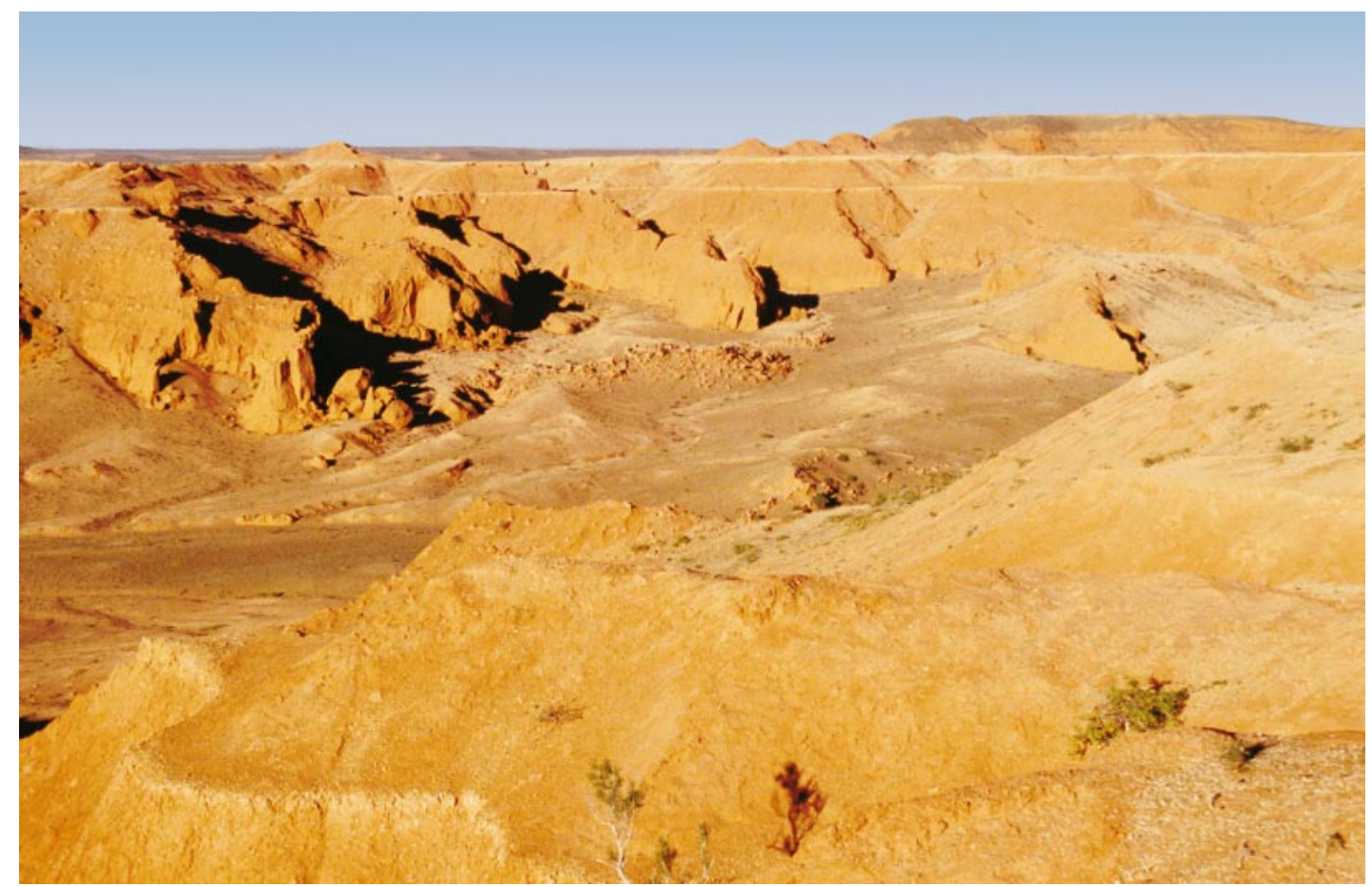

Fig. 5. View looking east at the western face of the main escarpment of the Flaming Cliffs, showing the two beds of light gray conglomerate (Units 4 and 6) near the top of the exposures.

(1998). There, the structureless units contain pebbles and cobbles floating in the sandy matrix that were much too large and heavy to be carried by the wind. This and the field relations of the structureless sand bodies, which were shingled in between cross-bedded sand bodies typical of eolian dunes, provided evidence that the structureless sands were deposited as sandslides at the base of the dunes (Dingus et al., in review). This interpretation differs from that of Eberth (1993), who interpreted structureless sandstone sheets at Bayan Mandahu to represent vertically agrading, eolian sands that accumulated during very high energy wind storms, possibly in zibars.

Structureless sands that comprise Units 5, 7,8 , and 9 of the present study are more difficult to interpret environmentally. They are interbedded with caliche pebble conglomerates (see facies 3 below) that clearly represent a fluvial environment. At least one of the structureless sandstone units (\#9) contains fossils of lizards and turtles. These structureless sandstone units probably also represent fluvial deposits.

2. Concretionary sheets of sandstone forming large-scale crossbeds dominate Unit 2 of this study. These sheets consistently dip with an azimuth to the northeast at $20^{\circ}-30^{\circ}$. Rare chunks of these concretionary layers contain in situ fossils of mammals. More commonly, nodules occuring as float on these outcrops contain fossils of mammals and lizards. Outcrops where these concretionary sheets dip with an azimuth to the northeast are interpreted to represent eolian crossbeds of Cretaceous dune deposits. These units are mapped as Kcon. Similar concretionary calcite underlying now buried dune lee slopes has recently been described from Quaternary eolian deposits in western China by Yang et al. (2003). Rhizoliths (calcite-replaced plant roots) are common within this facies. A similar facies, lacking rhizoliths, is present at Ukhaa Tolgod (E-2 facies of Dingus et al., in review).

3. Relatively thin beds of white calcareous 
caliche containing basal pebbles of caliche and subordinate clasts of crystalline rock dominate Units 4 and 6 of this study. These units are unfossiliferous. They are interpreted to represent fining upward beds deposited by fluvial action. They are mapped as Kcal, and one can be traced across the Flaming Cliffs exposures for more than $1 \mathrm{~km}$.

4. Beds of siltstone and mudstone, mapped as $\mathrm{Km}$ on map 2, occur as lenses interbedded with the structureless sands of facies Ks. These units are not laterally continuous for more than $100 \mathrm{~m}$, and they are not fossiliferous. They are interpreted to represent finegrained interdune units deposited in shallow ponds and depressions by fluvial action.

These facies can be mapped across the Bayn Dzak region, as was done using air photos taken in August of 1996. The facies are exposed on and to the north of a 7-kmlong scarp that separates a plateau capped by Quaternary pediment to the south and a basin filled with Quaternary colluvium, alluvium, and eolian dune deposits to the north. The eastern leg of the scarp trends nearly east to west, beginning just west of the Khatato Gol and extending to the main exposures of the Flaming Cliffs. The western leg of the scarp trends more northwest and extends past the Ruins to the Volcano.

Most of the eastern leg of the scarp is formed by Ks. Isolated outcrops of Kcon protrude out of the Quaternary colluvium that forms the floor of the basin to the north of the scarp. Many of these outcrops are formed by concretionary sheets representing Unit 2. Fourteen attitudes were measured on these sheets. The azimuths of dip directions on these sheets interpreted as large-scale eolian crossbeds range from $\mathrm{N} 25^{\circ} \mathrm{E}$ to $\mathrm{N} 85^{\circ} \mathrm{E}$. Near the top of the scarp, a prominent bed of Kcal can be traced along the western quarter of the eastern leg. It sits immediately on top of Unit 3, which represents the structureless sands that comprise most of the exposures that form the Flaming Cliffs proper.

The Flaming Cliffs themselves, capped by Qp, jut northwest out from the plateau into the basin to the north. A small northeastsouthwest trending fault cuts across the southern end of the Flaming Cliffs. Offset is between $1 \mathrm{~m}$ and $2 \mathrm{~m}$, with the northwest block containing the Cliffs being down- dropped in relation to the southeast block that forms the main plateau capped by Qp. Another small fault trending nearly east to west cuts across the northern end of the Cliffs. A remnant of the Cliffs exposures sits to the north of this fault. The base of the remnant is formed by Kcon of Unit 2, but the higher parts of the remnant are capped by Ks of Unit 3. The remnant appears to represent a block of the Flaming Cliffs exposure that has dropped 3-5 $\mathrm{m}$ along the fault in relation to the main units that form the extant Cliffs. The prominent Unit 4 of Kcal can be traced completely around the top of the main Cliffs exposures immediately on top of the prominent cliff-forming $\mathrm{Ks}$ of Unit 3. The Kcal of Unit 4 is extremely well cemented and resistant. It clearly protects the poorly consolidated sands of Unit 3 from more accelerated erosion and allowed the distinctive geomorphologic relief of the Flaming Cliffs to develop.

At the base of the northwest corner of the Flaming Cliffs lies a distinctive set of concretionary sandstone sheets composing Kcon of Unit 2. Ten attitudes recorded on these sheets reveal dip directions with azimuths ranging from $\mathrm{S} 6^{\circ} \mathrm{E}$ to $\mathrm{N} 10^{\circ} \mathrm{E}$, with most attitudes between $\mathrm{N} 25^{\circ} \mathrm{E}$ and $\mathrm{N} 50^{\circ} \mathrm{E}$. Again, these sheets are thought to represent largescale eolian crossbeds.

A prominent northwest-southeast trending drainage lies immediately west of the main exposures of the Flaming Cliffs (fig. 5). In the exposures along the southwest side of the drainage, the prominent Kcal of Unit 4 can be traced for about $600 \mathrm{~m}$ to the northwest where it pinches out. In the southernmost exposures of the scarp along the southwest side of the drainage, isolated outcrops of Kcon appear to be shingled in between outcrops of Ks. Rhizoliths oriented parallel to the crossbedding are prominently preserved on the tops of the sheets (Loope and Dingus, 1999). This sequence represents one of the clearest examples of the field relations between the eolian crossbedded sheets of Kcon and the structureless sandslides of Ks exposed in the Bayn Dzak region. Six attitudes were recorded on the concretionary sheets in this area. The azimuths of dip directions range from $\mathrm{N}$ $20^{\circ} \mathrm{E}$ to $\mathrm{N} 35^{\circ} \mathrm{E}$.

Just northwest of these exposures a small 


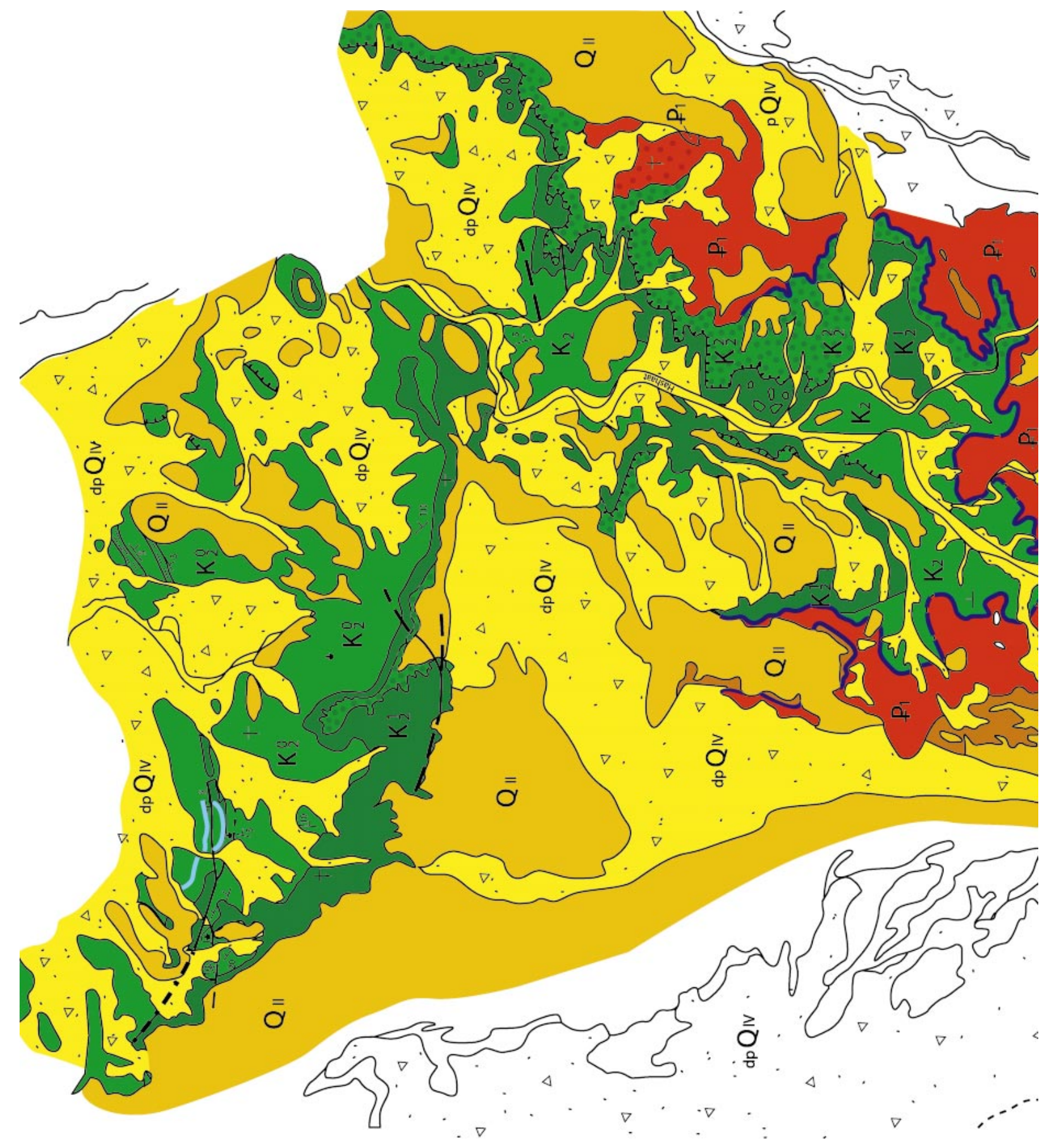




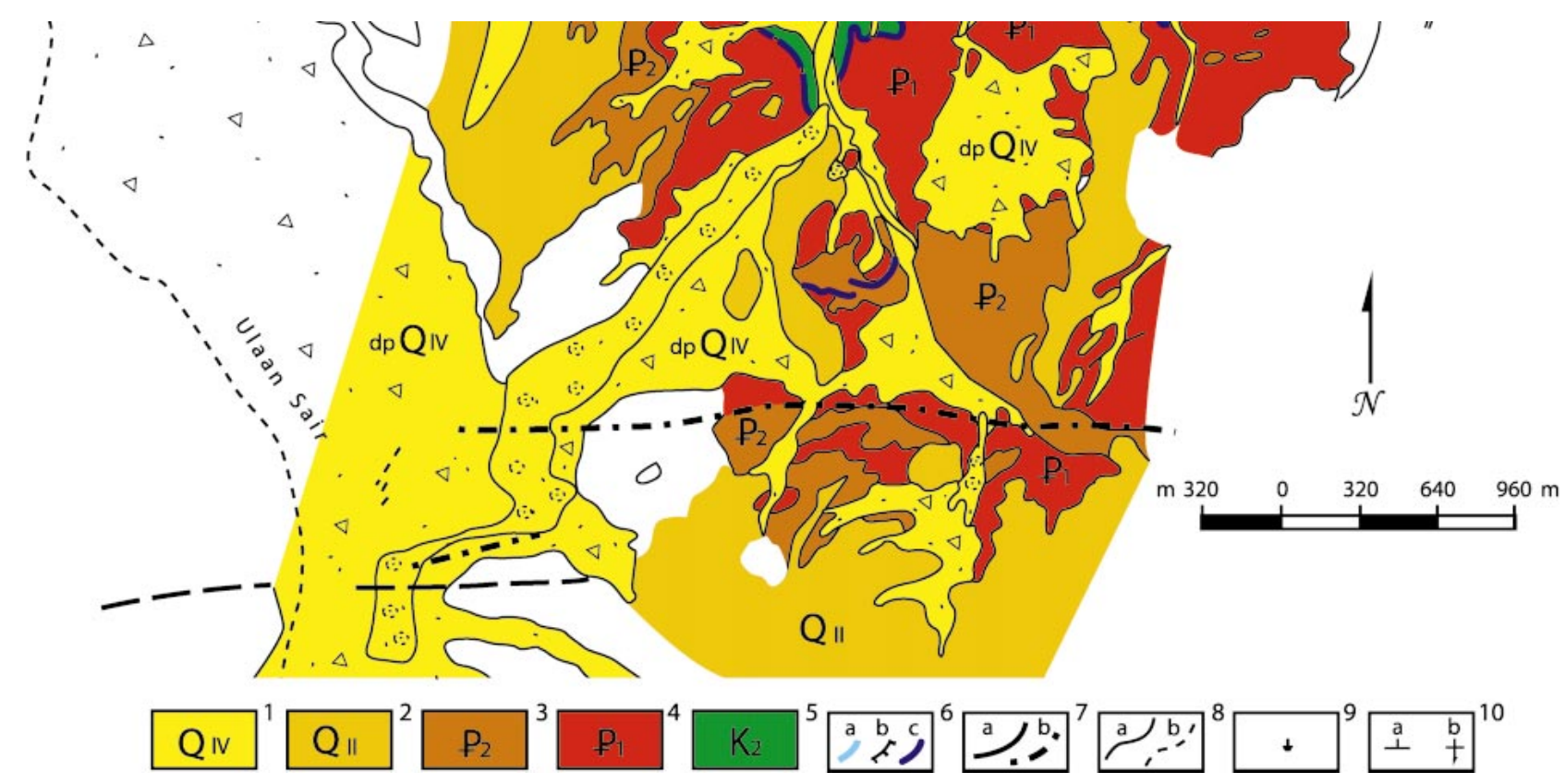

Map 1. Geologic map of major lithologic units at Bayn Dzak. Compiled by T. Dulam in July 1998.

1. Holocene eolian sands vQiv; deluvid sands dpQiv; lake clay and sand lQiv; proluvial sand and debris pQiv.

2. Pleistocene deluvial-prodeluvial sands and debris, partly with limy matrix.

3. Eocene; small grained shingles composed of less rounded and less sorted sands, and thin layers of white limy marl $(1-2 \mathrm{~cm})$.

4. Paleocene; Hashaat Suite: coarse-grained sands of brownish yellow, red, and greenish colors with thin layers of shingled red and reddish brown clay, and greenish gray aleurite, marl.

5. Upper Cretaceous; Bayn Dzak Member: K0/2 lightly colored sandstone, sand, K1/2 reddish, weakly lithified, small-medium-grained sand. In the lower part of the section, horizontally oriented sandstone nodules are common. K2/ 2 non-lithified red sands, rich with mud craters, footprints, and fewer sandstone nodules.

6. Reference horizons. a: white horizon with hard calcareous sandstone nodules. b: white conglomerates and layers of marl with reworked marl nodules. c: brecciated marl with lithic fragments.

7. Faults: a: known; b: inferred.

8. Geologic boundaries: a: clear; b: unclear.

9. Points of observation of fossil bone.

10. Orientation of bedrock: a: inclined; b: horizontal.

The entire undivided map may be printed from the AMNH library catalog at http://library.amnh.org/pubs. 


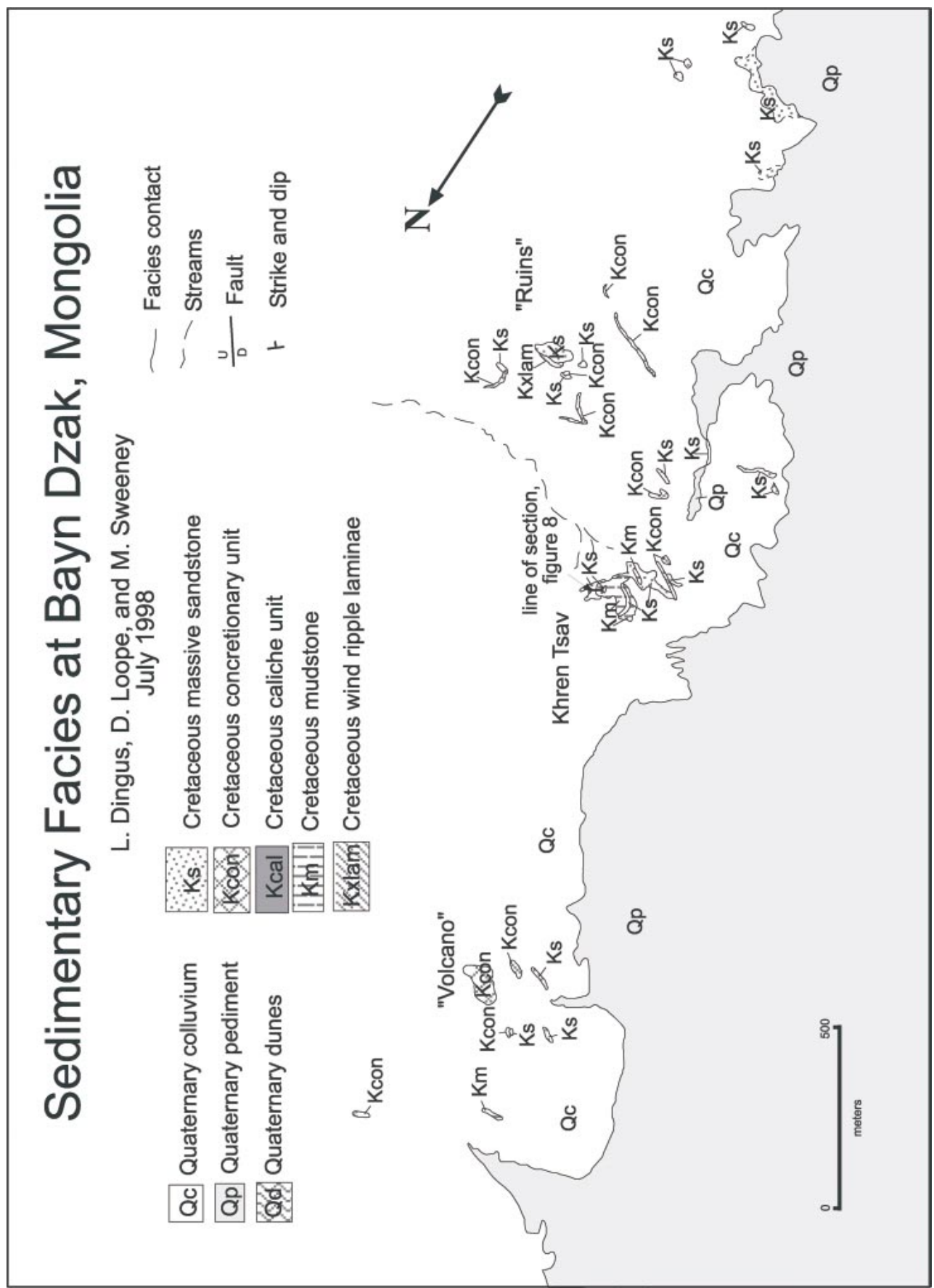

Map 2. Facies map of Bayn Dzak Member at Bayn Dzak. The map has been divided into two halves. The left half (this page) represents the northwest portion of the study area, which extends from the Volcano to the Ruins. 


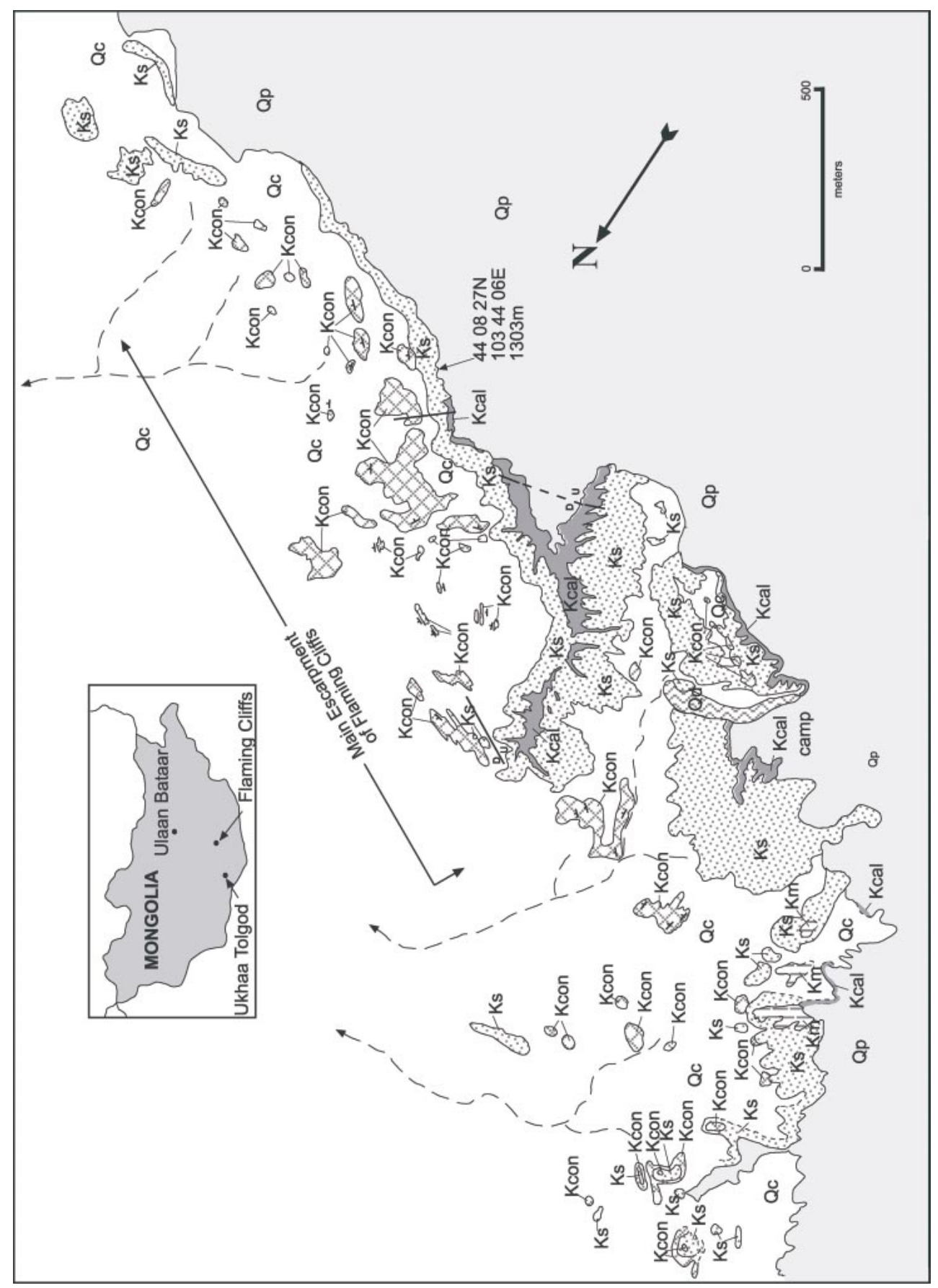

Map 2. Continued. The right half (this page) represents the southeast portion, which includes the Main Escarpment of the Flaming Cliffs. The line of section for fig. 2 is plotted just northwest of 4408 $27 \mathrm{~N}, 1034406 \mathrm{E}$. The entire undivided map may be printed from the AMNH library catalog at http: //library.amnh.org/pubs. The map was compiled by L. Dingus, D. Loope, and M. Sweeney in July 1998. 


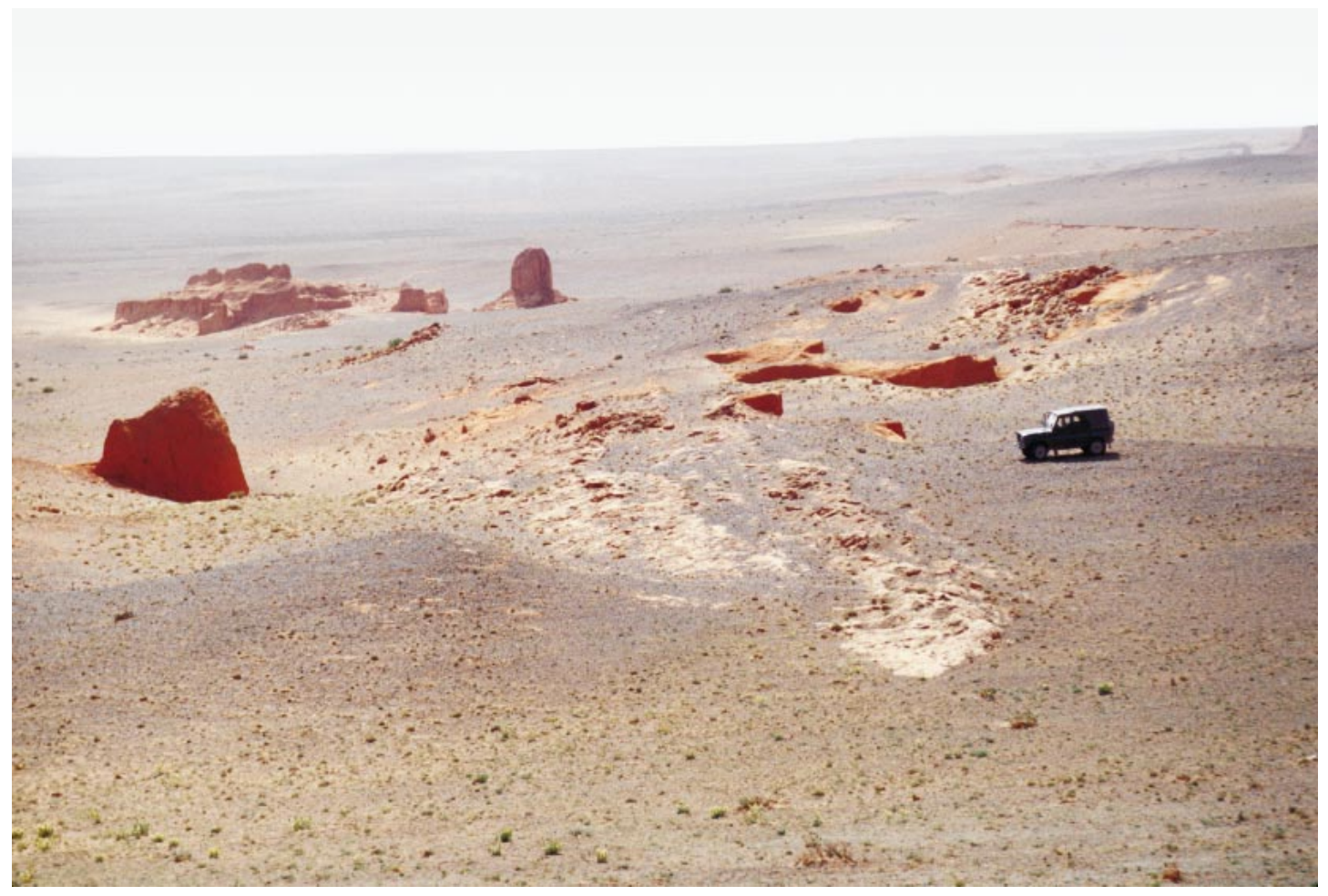

Fig. 6. View looking east from the western rim of the basin at Bayn Dzak at exposures of the Ruins.

northeast-southwest trending drainage is flanked on the northwest by a large modern sand dune (Qd). Our camp usually occupies the point on the Qp-capped plateau just northwest of this dune.

From our camp, the scarp trends more northwest toward the Ruins and the Volcano. About $750 \mathrm{~m}$ northwest of camp, three distinctive mudstone units are exposed in the lower portion of the scarp. They crop out as laterally discontinuous lenses and represent small interdune deposits interbedded with structureless sands of Unit 3 that lie above the concretionary sheets of Unit 2 .

Two kilometers northwest of the Flaming Cliffs lies the prominent scarp remnant named the Ruins by the PMPE (fig. 6), which provided skeletons of the long-necked crocodile, Gobiosuchus kielanae (Osmólska, 1972). An exposure of wind-rippled, crosslaminated sand occurs on the northern side of the remnant. Concretionary sheets of sandstone, presumably representing Unit 2, lie at the base of the remnant. The Ruins are capped by structureless sands (Ks) containing occasional dinosaur skeletons and abundant trace fossils. Presumably these sands represent Unit 3.

About $700 \mathrm{~m}$ northwest of the Ruins lie the exposures of Khren Tsav (fig. 7). The section exposed here (fig. 8) is quite significant. The basal $10 \mathrm{~m}$ are composed of moderate reddish orange, structureless sandstone (Ks), probably representing Unit 3 exposed at the Flaming cliffs. Vertebrate fossils, including a skull and skeletal fragments of $\mathrm{Za}$ lambdalestes, were collected in situ. Trace fossils of Ophiomorpha are also abundant. In the main hill at the site, the structureless sands, probably representing fluvial deposits, are immediately overlain by $5 \mathrm{~m}$ of orangish brown mudstone $(\mathrm{Km})$, representing fluvial pond deposition. The sequence is capped by 2-3 m of moderate reddish orange structureless sand. However, just west of the main hill, at the stratigraphic level of the mudstone, concretionary sheets of sandstone (Kcon) crop out. Four attitudes representing 


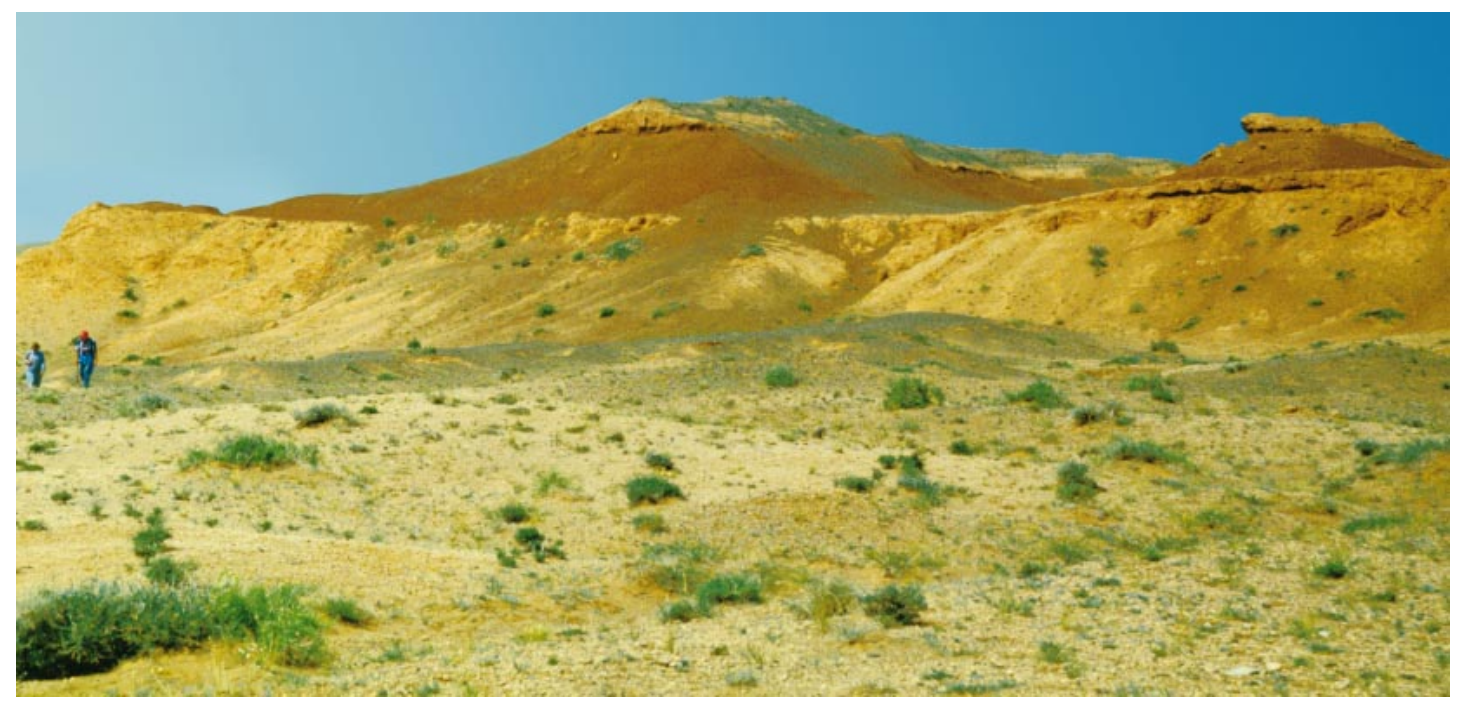

Fig. 7. View looking west at the exposures of Khren Tsav showing the prominent unit of brown mudstone interpreted to represent interdune deposition by fluvial processes in ephemeral lakes or ponds.

dip directions on these sheets range from azimuths of $\mathrm{N} 18^{\circ} \mathrm{E}$ to $\mathrm{N} 30^{\circ} \mathrm{E}$. The contact between these units is either eroded or not exposed. However, three environmental facies appear to be represented in close lateral proximity: eolian dune deposits represented by the crossbedded concretionary sheets, fluvial sands represented by the structureless and fossiliferous sandstone, and interdune fluvial pond deposits represented by the mudstone.

Almost $2 \mathrm{~km}$ further northwest of the $\mathrm{Ru}$ ins lies the locality named the Volcano by the PMPE. Most of the conical remnant of the scarp is covered by colluvium; however, a few outcrops are exposed. A couple of patches of structureless concretionary sandstone lie at the base. Nodules in these massive concretions contain fossils of lizards, crocodiles, dinosaurs, and mammals. Above near the peak, a small patch of concretionary sandstone is overlain by a small outcrop of structureless sandstone containing abundant rhizoliths_-among the best examples in the Bayn Dzak area. It is unclear how these outcrops correlate with exposures to the southeast because of extensive intervening covered areas.

\section{STRATIGRAPHIC POSITION OF MAMMALIAN FOSSILS IN THE BAYN DZAK MEMBER}

In 1924 and 1925 the CAE discovered Cretaceous fossils of mammals and small dinosaurs at the Flaming Cliffs. However, neither the geographic position of the mammalian locality nor the stratigraphic position of the fossiliferous units in the Flaming Cliffs section were precisely reported (Efremov, 1954). The fossils were merely reported to have been found in small concretions. The mammalian fossils described from the formation are the following.

During fieldwork by the MPE, Novojilov (1954) studied the stratigraphic position of mammalian fossils from Bayn Dzak. He suggested that the Cretaceous mammalian fauna was derived from a concretionary bed in the formation below the Paleocene fossiliferous exposures to the southeast discovered by the CAE called Hashaat.

Geological investigations at Bayn Dzak were pursued in greater detail by the PMPE (Gradziński et al., 1969, 1977; Lefeld, 1965, 1971). The PMPE confirmed the occurrences of Cretaceous deposits of the Djadokhta Formation. Fossils were reported from three lo- 
TABLE 1

The Bayn Dzak Fauna

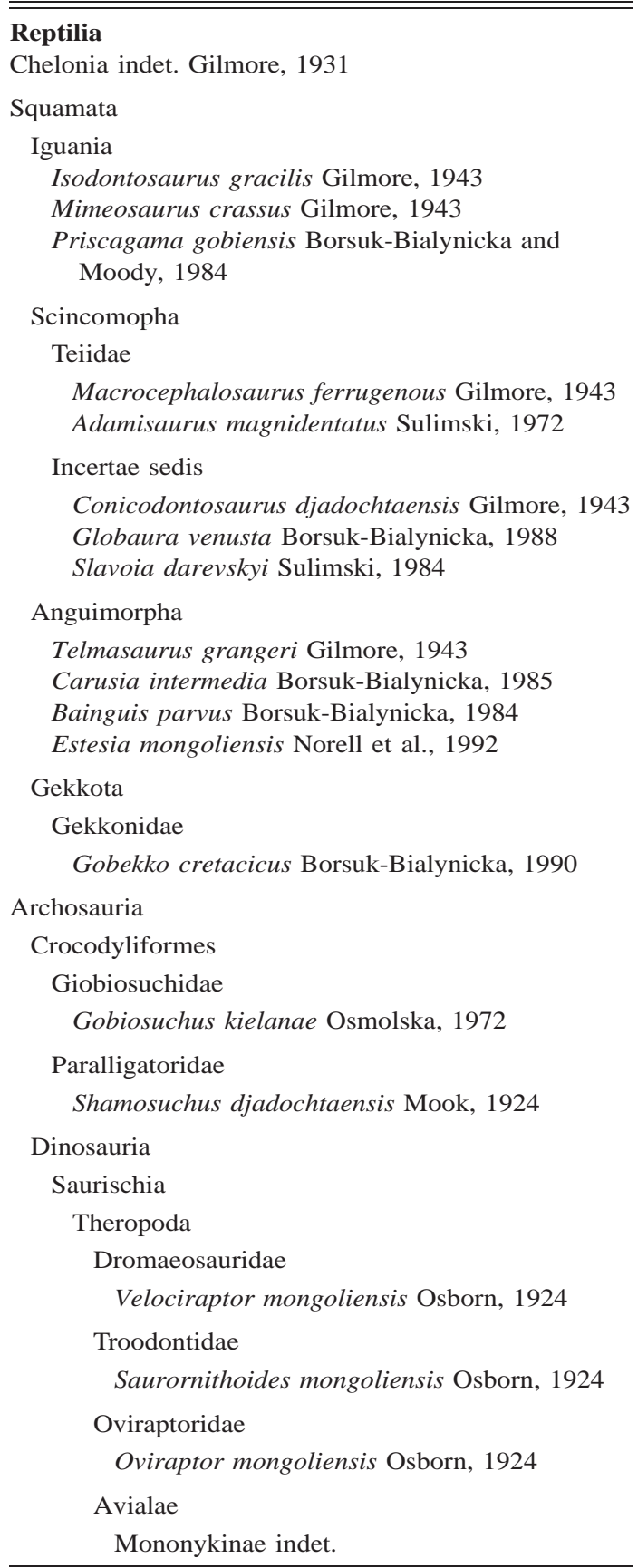

TABLE 1

(Continued)

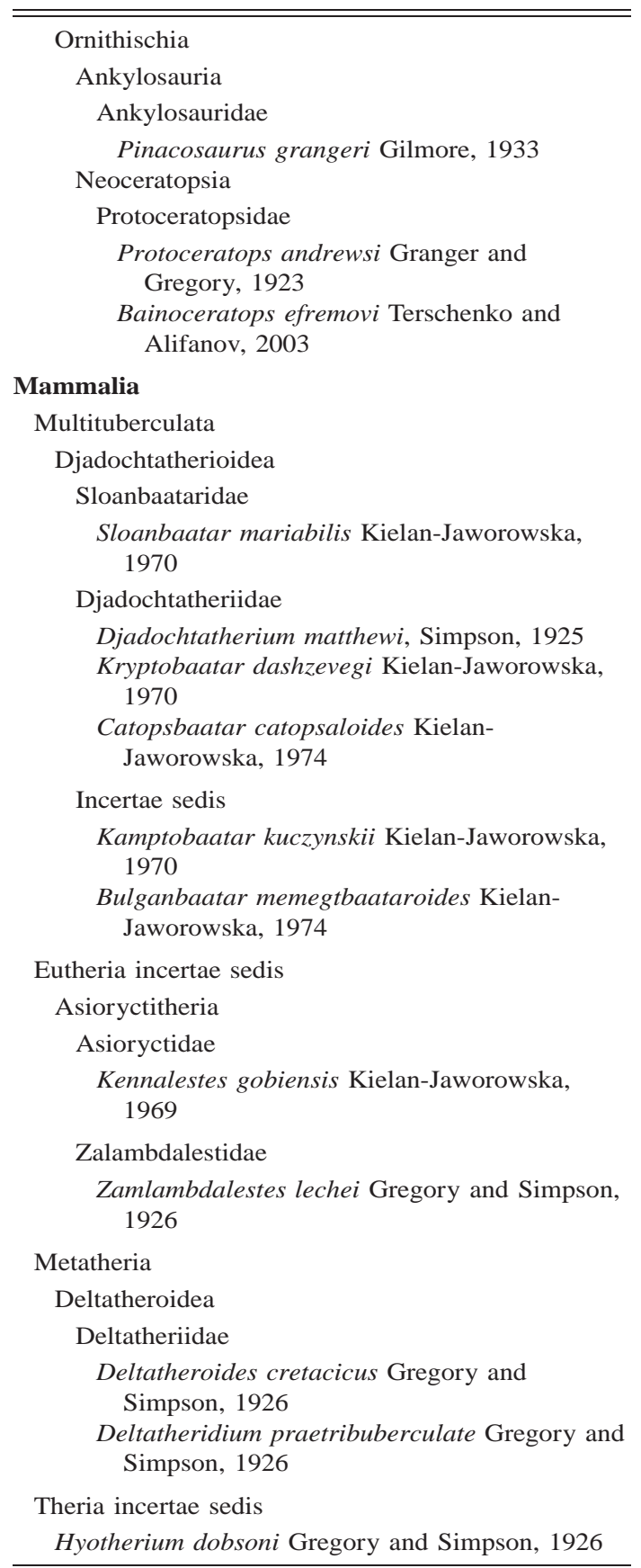


calities: (1) the Main Mammal Field, along the eastern margin at the base of the Flaming Cliffs; (2) the Ruins, about $2400 \mathrm{~m}$ to the northwest of the Flaming Cliffs; and (3) the Volcano, about $2 \mathrm{~km}$ to the north of the Ruins, where the lower Kcon nodules produced remains of mammals and other vertebrates. According to Polish accounts (Kielan-Jaworowska, 1969, 1970; Gradziński et al., 1977) these three localities yielded numerous skulls and jaws of mammals as well as abundant fossil remains of lizards, crocodiles, and other vertebrates. Several mammal specimens have been found in situ in all three above mentioned localities. So, restriction of the mammalian fossils to the Upper Cretaceous Djadokhta Formation was definitely established.

In 1991-1992, 1994-1996, and 1998 the Bayn Dzak locality was reinvestigated by the MAE, which made collections of the Cretaceous remains from the three PMPE localities (above), as well as from two new localities in the Bayn Dzak region. (1) A cranium and associated skeletal fragments of Zalambdalestes were collected from the basal, moderate reddish orange sands of the Khren Tsav section. (2) The cranium and jaws of placental mammals were found in the moderate reddish orange sandstones of Unit 5 along the scarp near the Flaming Cliffs. In 1971, a multituberculate cranium was also collected there by Dashzeveg.

\section{BIOCHRONOLOGIC INTERPRETATIONS FOR THE BAYN DZAK FAUNA}

The known vertebrate fauna from the Bayn Dzak Member is listed in table 1. Relatively recent studies discussing the lizard faunas from this area include Sulimski (1975), Borsuk-Bialynicka (1984, 1991a, 1991b), Gao and Norell (2000), and Alifanov (2000). Relatively recent references for the area's archosaurian fauna include Maryańska (1971, 1977), Osmólska (1972, 1976), Maryańska and Osmólska (1975), Norell et al. (1994), Chiappe et al. (1998), and Benton et al. (2000). Relatively recent papers concerning the mammalian fauna for the area include Kielan-Jaworowska (1970, 1975, 1984), Kielan-Jaworowska and Hurum (1997, 2001),
Kielan-Jaworowska et al. (2000), Novacek et al. (1997), Rougier et al. (1977, 1996, 1998), Smith et al. (2001), and Wible and Rougier (2000). Recent studies focusing on dinosaur and other fossil eggs from the area include Mikhailov (1994, 1995, 1996), Mikhailov et al. (1994), Sabath (1991), and Norell et al. (1994).

There are no radioisotopic dates from beds in the sequence that produce the Bayn Dzak fauna. According to different authors, its age has been reported to range from Cenomanian to Early Maastrichtian. Berkey and Morris (1927) placed it in the early Late Cretaceous. Polish authors variously assigned it to a range between the Coniacian and the Santonian (Gradziński et al., 1969; Kielan-Jaworowska, 1969, 1970, 1974; Kielan Jaworowska and Dovchin, 1969; Lefeld, 1965, 1971). McKenna (1969) suggested a Cenomanian age. Rozhdestvensky, in his study of Mongolian dinosaurs (1971), inferred the probable age of the fauna to be late Santonian or possibly early Campanian. Fox (1978) suggested a Campanian age based on comparisons between Mongolian, American, and Canadian dinosaurs from the Late Cretaceous. Lillegraven and McKenna (1986) considered the Bayn Dzak fauna to be of Campanian-Early Maastrichtian age. Jerzykiewicz et al. (1993) and Eberth (1993) assign a Campanian age to the Djadokhta faunas from both Bayan Mandahu and Bayn Dzak. Most recently, Averianov (1997) tentatively agreed with Gradziński et al. (1977) that the fauna from the Djadokhta Formation is early Campanian in age, based on comparisons of mammalian and marine taxa from the Darbasa Formation of Kazakhstan. So, although most recent workers have assigned a Campanian age to the fauna from the Djadokhta, there has historically been little consensus among biochronologic age estimates and no evidence independent of faunal comparisons.

\section{MAGNETOSTRATIGRAPHY OF THE BAYN DZAK MEMBER}

Magnetostratigraphic samples were collected for analysis from both the Flaming Cliffs and Khren Tsav sections (figs. 2, 8). A more detailed account of all the magneto- 
stratigraphic data for localities discussed in this paper is being prepared for a separate publication. The results are as follows.

At the Flaming Cliffs, Units 1 and 2 at the base of the section described here occur in a zone of normal polarity. Above, Unit 3, which comprises the principal cliff-forming sandstone, is reversed. The polarities of Units 4 and 5 are presently undetermined. Units 6 and 7 are of normal polarity, and the top of the section represented by Unit 8 is reversed.

At Khren Tsav (fig. 8) two samples in the lower structureless sandstone are reversed, suggesting but not establishing a correlation to Unit 3 of the Flaming Cliffs section. One sample in the overlying mudstone is also reversed (M. C. McKenna, personal commun.). One sample from the uppermost sandstone unit is also questionably reversed.

\section{MAGNETOSTRATIGRAPHIC IMPLICATIONS FOR THE AGE OF THE BAYN DZAK FAUNA}

The presence of reversed magnetozones in both the Flaming Cliffs and Khren Tsav sections means that most of these units must be younger than Chron 34n-the upper boundary of which represents the boundary between the Santonian and the Campanian at about 83.5 Ma (Gradstein et al., 1995). The quick stratigraphic succession of normal and reversed magnetozones in the Flaming Cliffs section suggests that the sediments were deposited during the rapid sequence of polarity changes in the late part of the Campanian incorporating the end of Chron 33 and Chron 32 between about 75 and $71 \mathrm{Ma}$ (Gradstein et al., 1995). However, this tentative correlation to the Geomagnetic Polarity Timescale cannot yet be certainly established.

\section{TRANSITIONAL DEPOSITS BETWEEN THE BAYN DZAK AND TUGRUGYIN MEMBERS}

Investigations by international paleontologic expeditions, which were conducted during the past 40 years, have greatly enhanced our knowledge of Cretaceous vertebrates from the Bayn Dzak and Turgrugyin Shireh localities. It was discovered that, although color differences characterize the
Bayn Dzak and Tugrugyin Members, these two localities produce many of the same dinosaur and mammal taxa, including Protoceratops andrewsi, Saurornithoides mongoliensis, Oviraptor philoceratops, Kryptobaatar dashzevegi, and Zalambdalestes leichei. The principal difficulty in establishing the geochronological succession between the Bayn Dzak and Tugrugyin deposits was the lack of sections containing transitional beds that document their superpositional relationships. In 1993-1996, the MAE investigated two such key sections.

The Tsonzh section. Dashzeveg discovered this section in 1984 , about $10 \mathrm{~km}$ to the southeast of the Flaming Cliffs. The low scarps at Tsonzh face north and pass upward into an inclined plateau that extends to the south (fig. 9A). Both the Bayn Dzak and Tugrugyin Members are exposed at Tsonzh, along with interbedded transitional lenses of mudstone (fig. 10). The lower Bayn Dzak Member is represented by well-sorted, moderate reddish orange sands. A tooth of Protoceratops andrewsi was found by Dashzeveg near the middle of this unit. Transitional beds are represented by lenses of compact brown mudstone, which rests in some places on the eroded underlying Bayn Dzak Member. The overlying Tugrugyin Member is represented primarily by yellowish gray to very light gray sands and sandstones (fig. 9). The transitional clay lenses are wedged into the sands of the Tugrugyin Member in some places. In 1993, the MAE collected scattered remains of a large theropod in the Tugrugyin Member. A paleomagnetic sample taken from the transitional reddish brown clay is reversed in polarity (M. C. McKenna, personal commun.)

The Alag Teer section. Dashzeveg discovered the Alag Teer (= Alag Teeg of Benton, 2000) section in 1964 (fig. 11). It lies $3.5 \mathrm{~km}$ from the main eastern scarp of Tugrugyin Shireh. The succession of beds is recorded in figure 12, and includes moderate reddish brown sandy siltstone at the base, overlain by interbedded moderate reddish orange sandstone and very pale orange sandstone. Above these lies yellowish gray sandy siltstone and interbedded moderated reddish orange sandstone and very pale orange sand- 


\section{Khren Tsav}

$\begin{array}{ccccc}m & \text { GSA } & \text { paleomag } & \text { sample } & \text { polarity } \\ 25- & \text { color } & \text { sample } & \text { polarity } & \text { zonation }\end{array}$

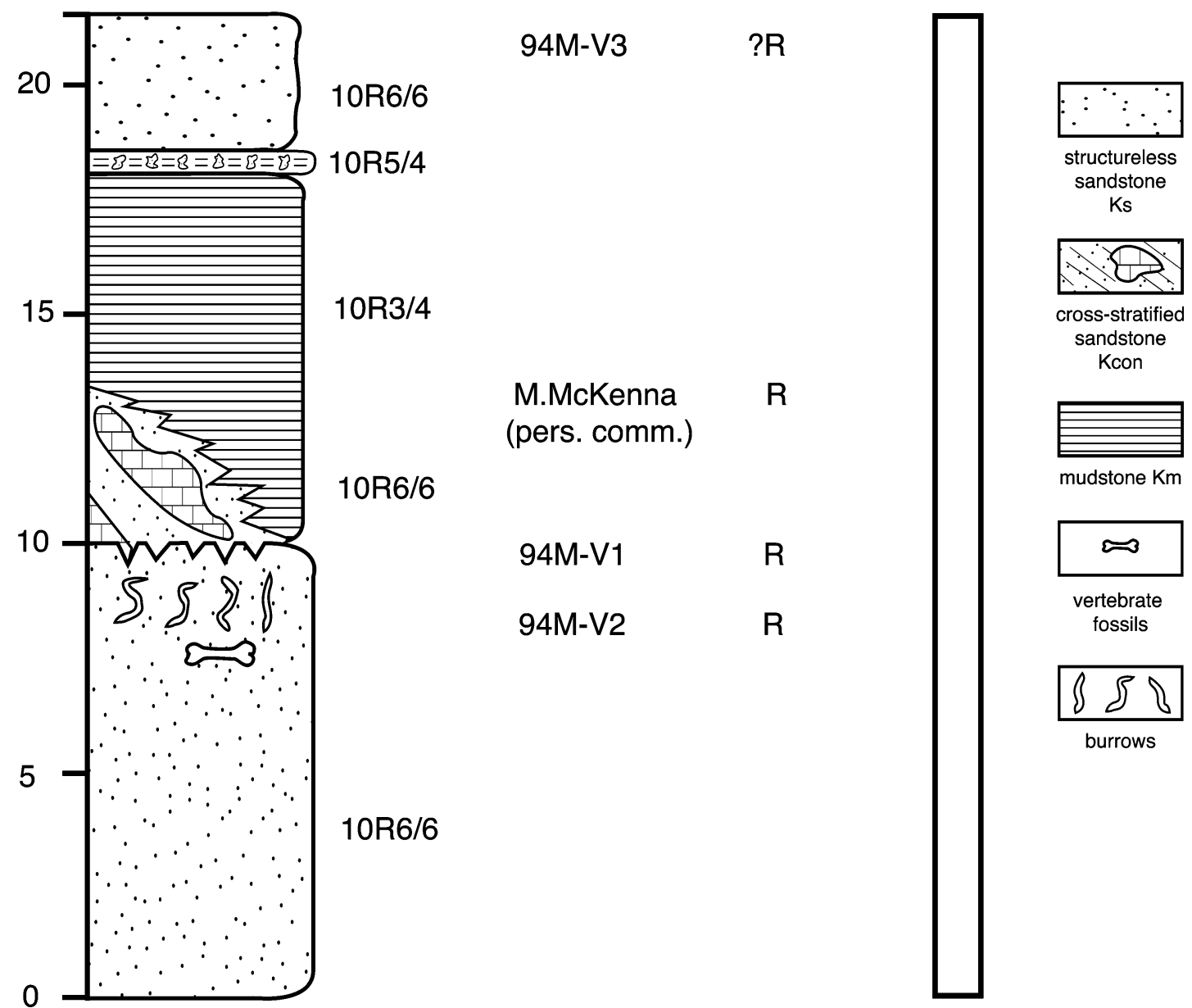

Fig. 8. Stratigraphic section at Khren Tsav. Paleomagnetic samples are listed to the right of the section. The lithologic key is on the right. The polarity of samples is listed to the right of the sample numbers.

stone. Very pale orange sandstone caps the section.

Like Tsonzh, this section is noteworthy for demonstrating the superpositional relationship between moderate reddish orange sandstones and moderate reddish brown mud- stone typical of the Bayn Dzak Member in the lower portion of the section and very pale orange sandstones typical of the Tugrugyin Member in the higher portion. The interplay between units typical of Bayn Dzak and Tugrugyin lithology, as well as the fact that typ- 


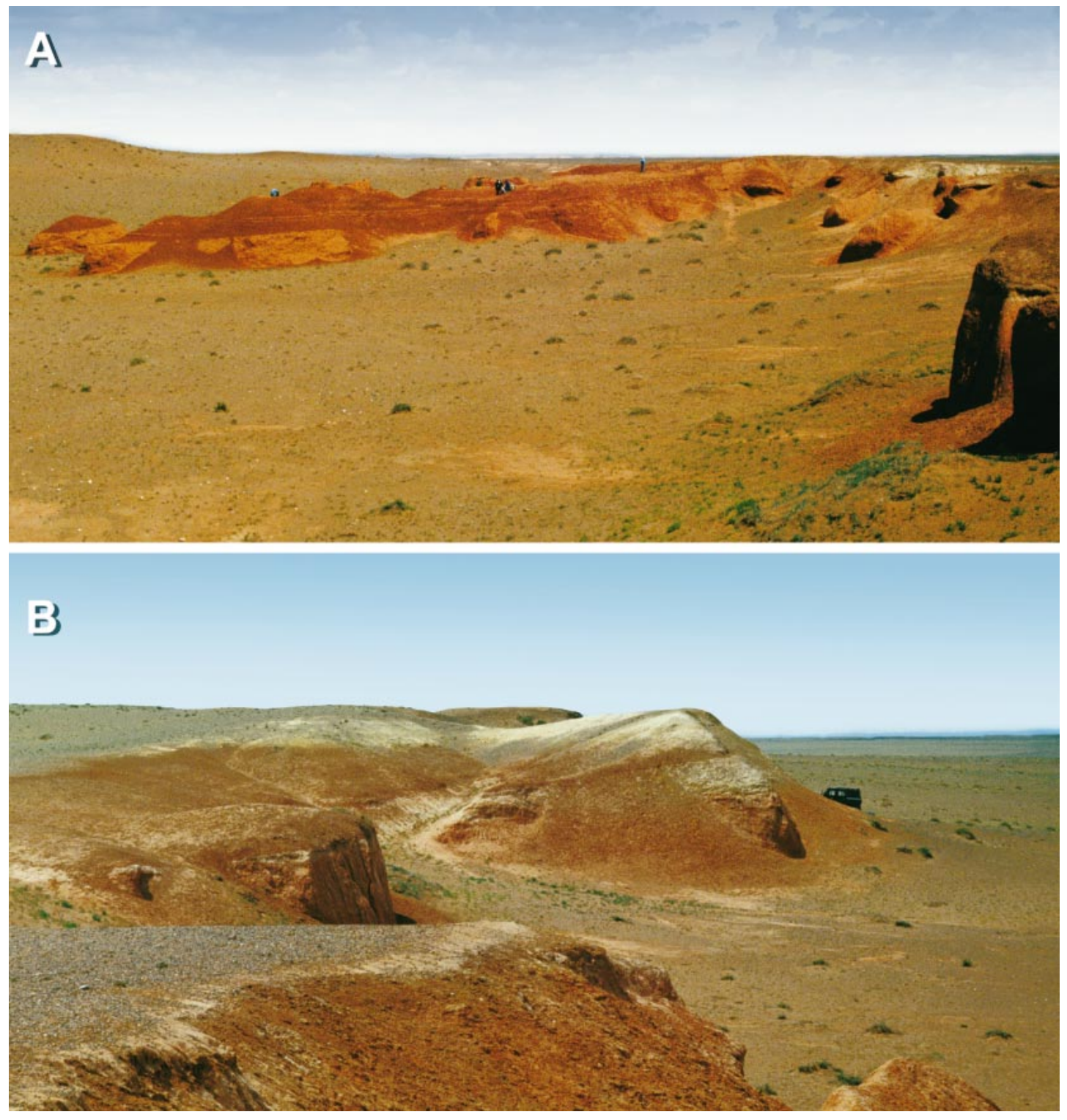

Fig. 9. A. Overview looking east at the eastern exposures of Tsonzh showing brown mudstone, similar to that exposed near the top of the section at Khren Tsav, wedged between underlying, structureless, reddish orange sandstone of the Bayn Dzak Member and overlying pale orange to light gray sandstone of the Tugrugyin Member. B. View looking west at the western exposures at Tsonzh showing reddish orange sandstone of the Bayn Dzak Member underlying pale orange to light gray sandstone of the Tugrugyin Member.

ical Bayn Dzak units underlie the typical Tugrugyin units as at Tsonzh, suggest that this sequence documents a transition between the Bayn Dzak and Tugrugyin Members. Unit 5 at Aleg Teer represents the base of the typical Tugrugyin sands exposed in the main scarp at Tugrugyin Shireh (see next section). So, the Alag Teer section is a direct lateral extension of the deposits at Tugrugyin Shireh; however, the stratigraphically lower transitional units exposed at Alag Teer are not exposed at Tugrugyin Shireh. 


\section{Tsonzh}

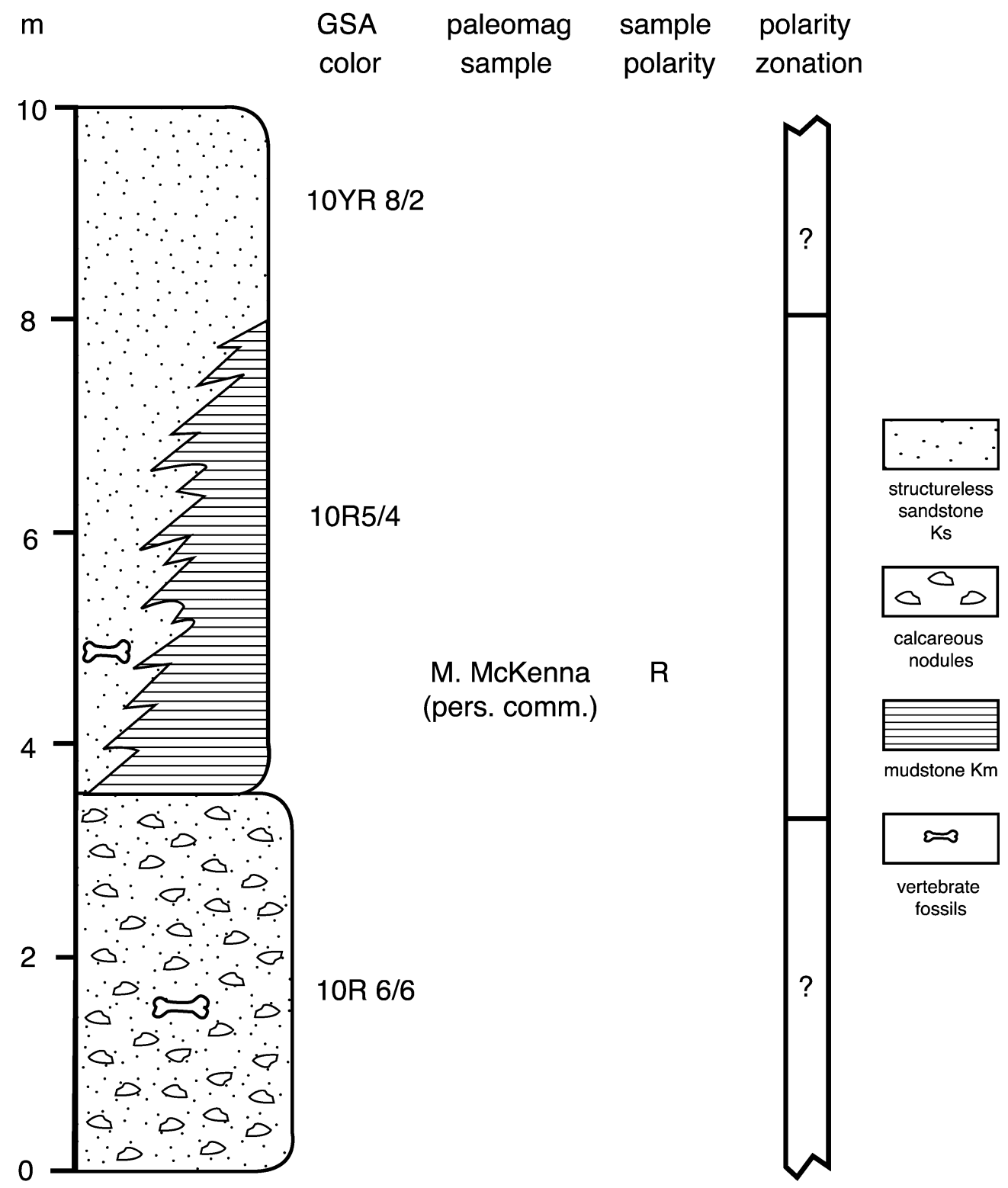

Fig. 10. Stratigraphic section at Tsonzh. The lithologic key is to the right of the magnetostratigraphic data.

Dinosaurs from Aleg Teer are restricted to Unit 2, which contains the alternation of Bayn Dzak and Tugrugyin sandstones. Fossils of hadrosaurs and Pinacosaurus were found in the Tugrugyin sands in the main exposure at Alag Teer (Fastovsky et al., 1997; Watabe and
Suzuki, 2000). Plant remains occur commonly in the reddish brown mudstones.

Four magnetostratigraphic samples were collected and analyzed (fig. 12). The fact that the sandy siltstones at the base of the Aleg Teer section are of normal polarity indicates 


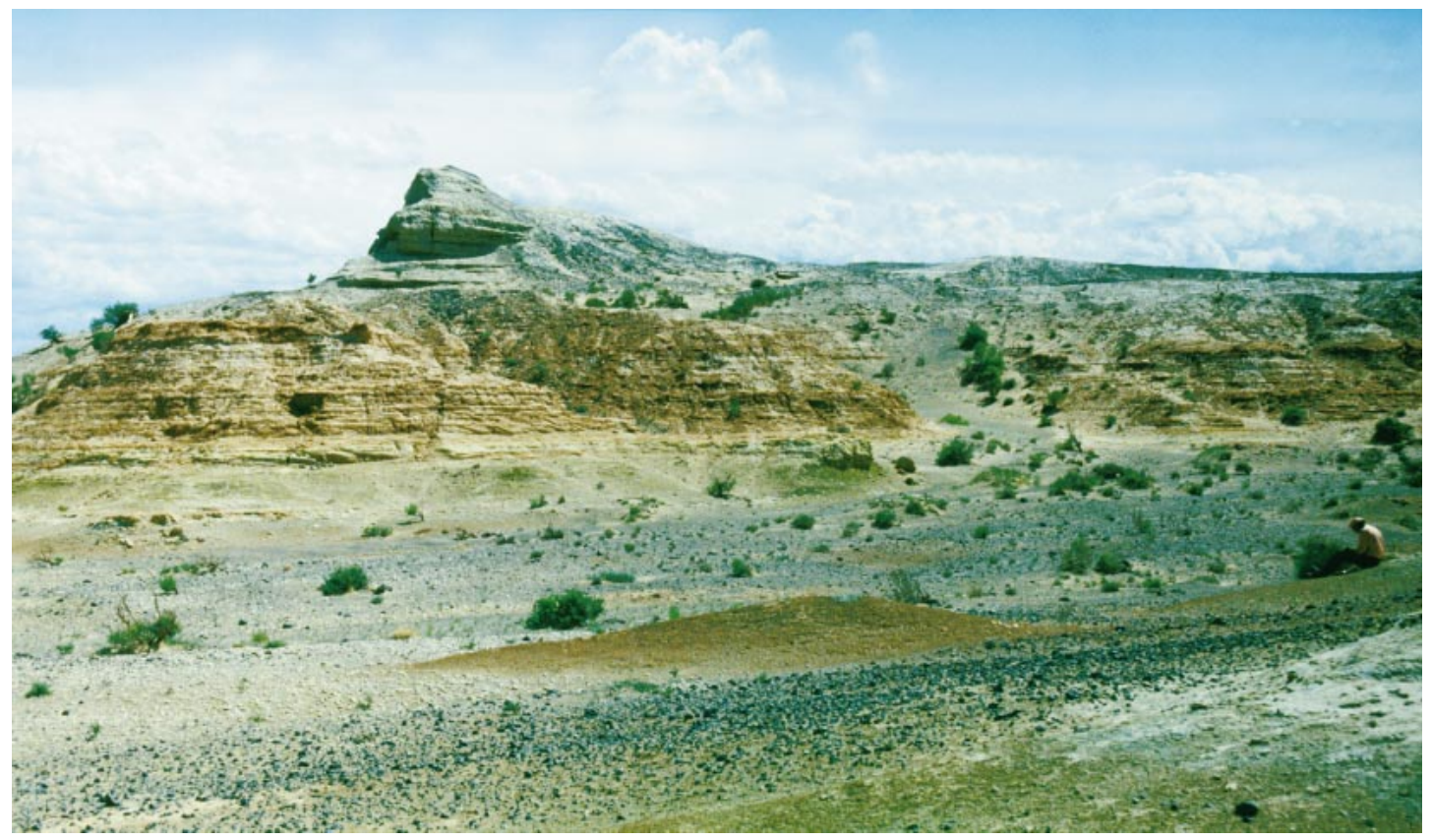

Fig. 11. View looking south at the exposures at Aleg Teer, just north of the exposures at Tugrugyin Shireh, showing reddish orange sandstone of the Bayn Dzak Member underlying pale orange to light gray sandstone of the Tugrugyin Member, identical to the superpositional relationships seen at Tsonzh.

that they formed at a different time than the transitional mudstones of reversed polarity at Khren Tsav and Tsonzh to the east.

\section{THE TUGRUGYIN MEMBER}

The key stratigraphic section is exposed at the Tugrugyin Shireh locality, $23 \mathrm{~km}$ to the northwest of the administrative center at Bulgan. The section was discovered by Dashzeveg in 1963. Two years later, Nikoloff and Dashzeveg revisited it (Nikoloff and Huene, 1966). The Tugrugyin Shireh locality is a scarp about $2.5 \mathrm{~km}$ long capped by a plateau of Quaternary pediment (fig. 13A,B). The exposures of the scarp are monotonous light gray sands and sandstones. The Tugrugyin Shireh scarp faces south, and the plateau is inclined to the north.

The locality was investigated by the PMPE and by the SMPE in 1969-1974 (Belyaeva et al., 1974). This locality produced the interlocked specimens of Velociraptor and Protoceratops referred to as the "fighting dinosaurs" (Kielan-Jaworowska and Barsbold, 1972; Osmólska, 1993). Most re- cently, the locality was reviewed by Fastovsky et al. (1997) and results of the JMJPE are summarized in Watabe and Suzuki (2000). The lizard fauna, in particular, was reviewed by Gao and Norell (2000), and the anatomy of a dromaeosaurid skeleton was described by Norell and Makovicky (1997).

Fastovsky et al. (1997) document three stratigraphic sections across the scarp totaling $30 \mathrm{~m}$. The sandstones of the Tugrugyin Member are described as thickly bedded, with large-scale, high-angle crossbeds distinctive of eolian dune slip faces. The crossbeds dip with an azimuth to the east-northeast, indicating predominantly westerly winds in the region during the Cretaceous. Three types of trace fossils are described and attributed to burrowing, probably by arthropods. Articulated skeletons of Protoceratops are common and often oriented parallel to the east-northeast dip direction of the crossbeds. Fastovsky et al. (1997) attribute their death to both sandstorms and less dramatic causes. The paleoenvironment is thought to represent a distal, basinward setting on a nearby braid- 


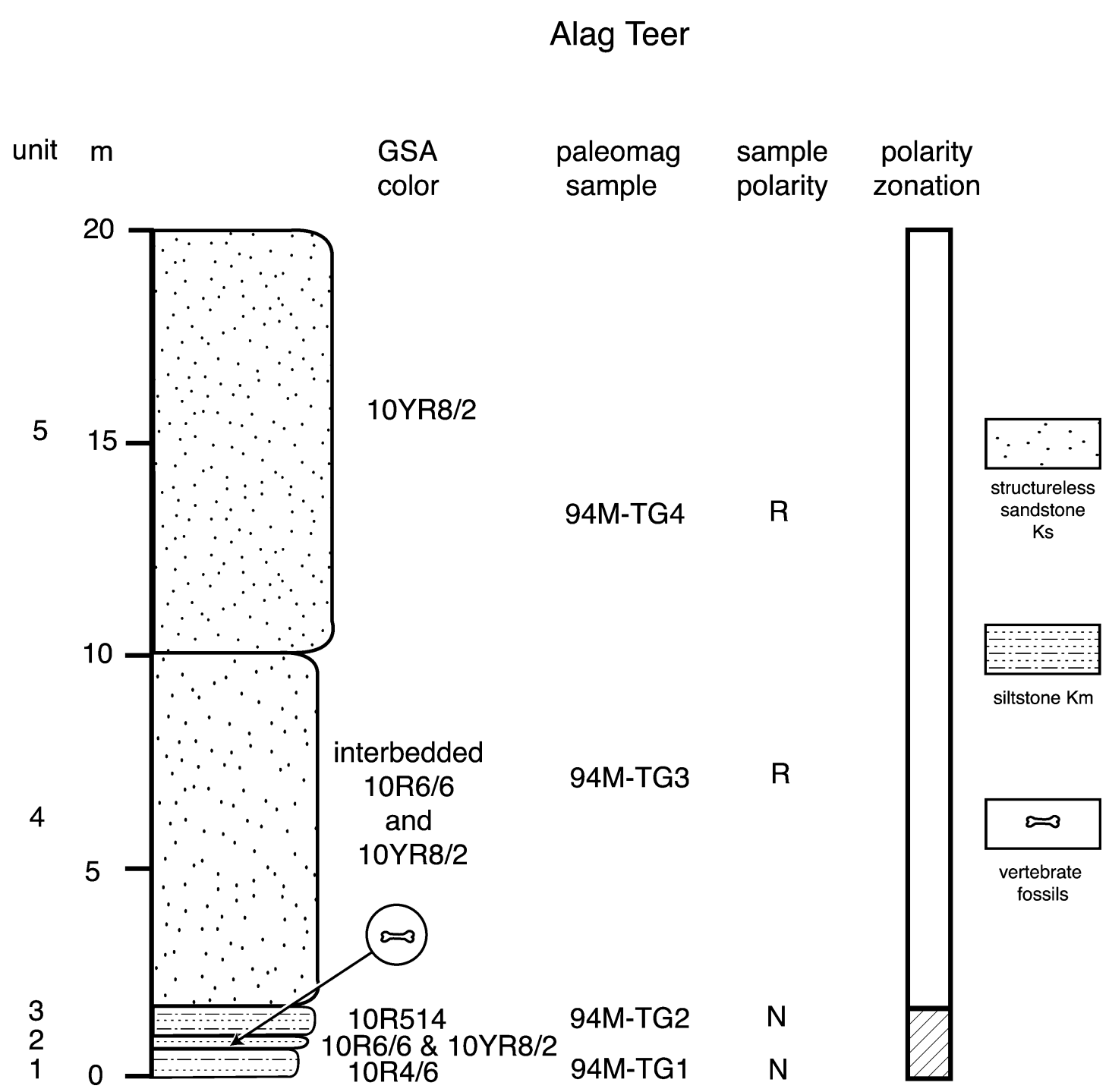

Fig. 12. Stratigraphic section at Alag Teer. The lithologic key is to the right. Unit numbers of this paper are listed to the far left of the section. Colors are based on the GSA color chart. The position of samples is listed to the immediate right of the colors. The polarity of samples is shown to the right of the sample numbers. Polarity zonation is at the far right.

plain-to-eolian suite of depositional environments. This paleoenvironmental interpretation is in accordance with that suggested for Djadokhta Formation exposures at Bayan Mandahu in northern China studied by Eberth (1993).

\section{THE TUGRUGYIN SHIREH SECTION}

Our section documents $52 \mathrm{~m}$ of light gray, crossbedded, and structureless sands and sandstones belonging to the Tugrugyin Member at Tugrugyin Shireh (fig. 14). Crossbedded units are rich in trace fossils, as noted by Fastovsky et al. (1997). Crossbeds are defined by thin concretionary sheets composed of iron oxide-cemented carbonate. Crossbedded units are laterally traceable for less than several hundred meters. They are interbedded and laterally pass into massive units of structureless sands and sandstones. 

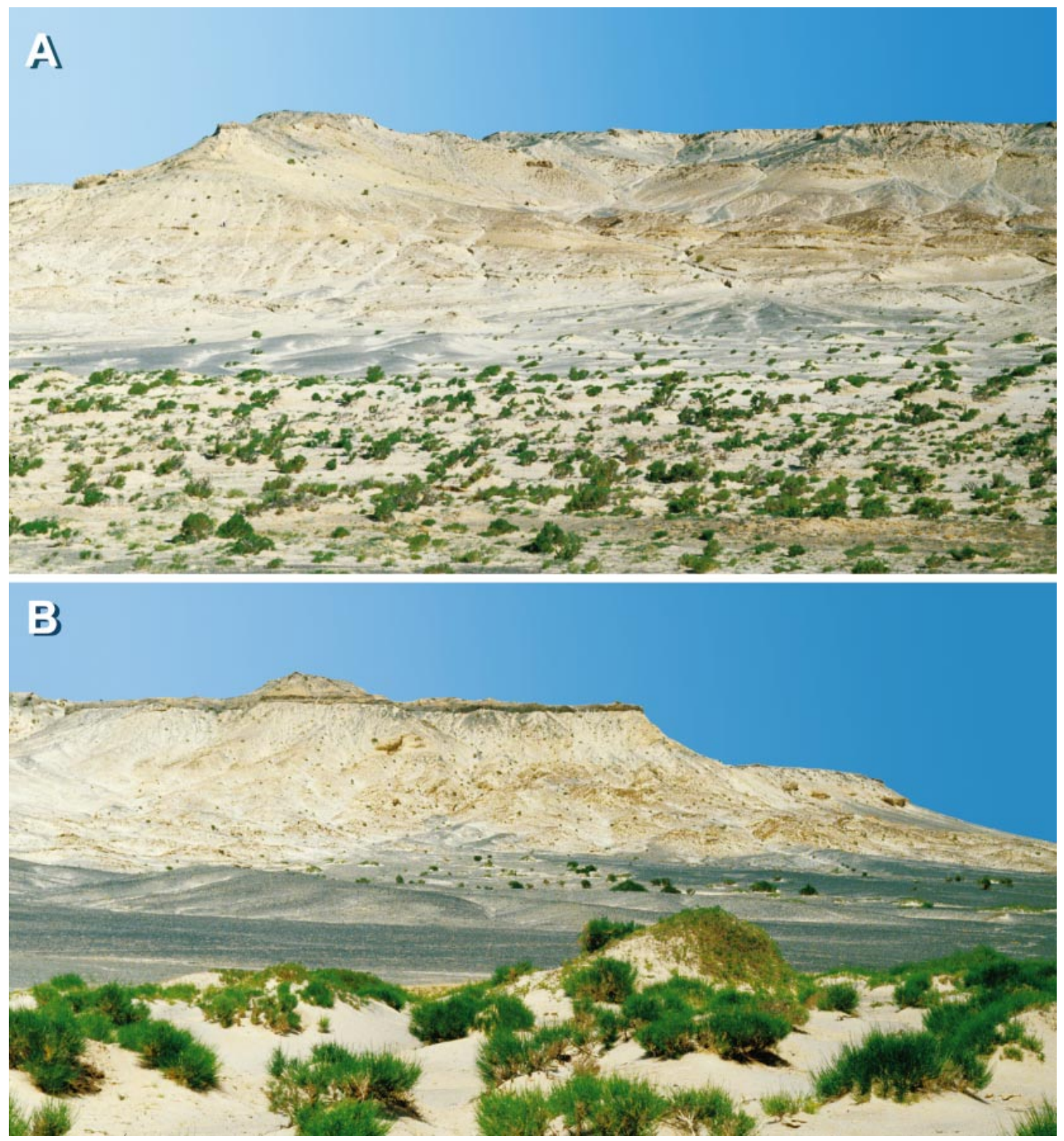

Fig. 13. A. View looking northwest at the western end of the main escarpment at Tugrugyin Shireh showing exposures of the Tugrugyin Member. B. View looking east at the eastern end of the main escarpment at Tugrugyin Shireh showing exposures of the Tugrugyin Member.

No facies map of the small-scale units at Tugrugyin Shireh is yet available; however, some preliminary observations can be noted as a basis for further testing during upcoming field investigations. Two distinct sedimentologic facies appear to be represented by the crossbedded sands and the structureless sands. We agree with Fastovsky et al. (1997) that the crossbedded sands represent sediment deposited by eolian processes on the lee faces of dunes. The massive structureless sands, however, exhibit no definitive sedimentary structures typical of eolian deposits. Instead, these could represent dune-derived 


\section{Tugrugyin Shireh}

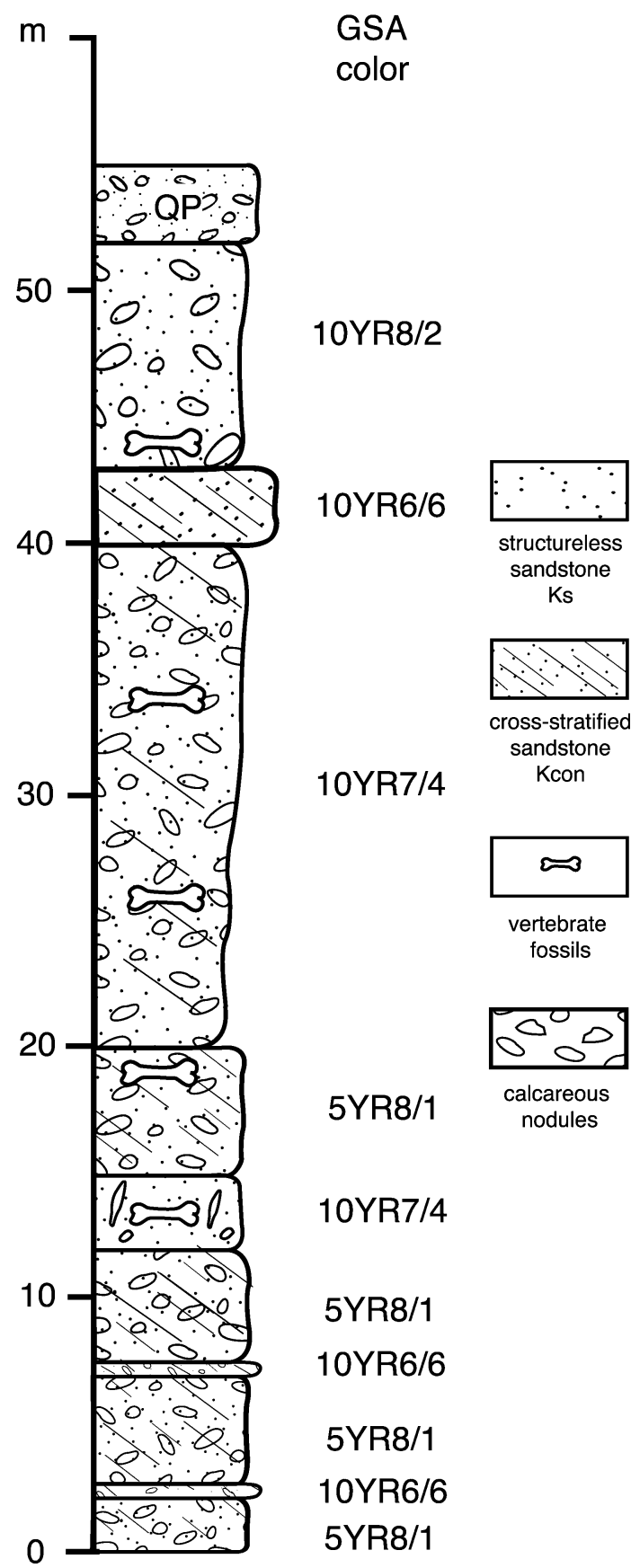

Fig. 14. Stratigraphic section at Tugrugyin Shireh. The lithologic key is to the right. The colors are based on the GSA color chart. sandslides generated on the lee faces of eolian dunes.

The known vertebrate fauna collected at Tugrugyin Shireh is listed in table 2. At least most of the large vertebrate skeletons and smaller fossils contained in irregular iron carbonate nodules are found in the structureless sands and sandstones, as at Ukhaa Tolgod. Vertebrate fossils collected by the MAE include Protoceratops andrewsi, Velociraptor mongoliensis, Shuvuuia deserti, Zalambdalestes leichei, Kryptobaatar dashzevegi (Rougier et al., 1996), and abundant lizard fossils (Gao and Norell, 2000).

\section{GEOLOGIC MAP OF MAJOR LITHOSTRATIGRAPHIC UNITS AT TUGRUGYIN SHIREH}

The oldest rocks in the mapped area consist of Late Cretaceous sands, primarily representing the Tugrugyin Member of the Djadokhta Formation with subordinate outcrops of the Bayn Dzak Member (map 3). They are exposed throughout the northern half of the mapped region in discontinuous patches, some of which contain outcrops of the moderate reddish orange sandstone of the Bayn Dzak Member at Aleg Teer. However in the southern half of the mapped area, sandstones of the Tugrugyin Member form a prominent arc beginning in the southwest corner that extends first to the east before turning north along the eastern edge of the map. The main escarpment of Tugrugyin Shireh forms the southernmost leg of this arc.

Overlying the Djadokhta Formation is a mixture of Quaternary alluvium, colluvium, and eolian sands. These are exposed throughout the mapped region.

\section{BIOCHRONOLOGIC INTERPRETATIONS FOR THE TUGRUGYIN SHIREH FAUNA}

As noted in tables 1 and 2, numerous taxa are found in both the Bayn Dzak and Tugrugyin Shireh faunas. Based on the stratigraphic relationships presented here it is clear that the Tugrugyin Member overlies the Bayn Dzak Member, making it somewhat younger. However, it is not yet possible to estimate the precise temporal difference. 
TABLE 2

The Tugrugyin Shireh Fauna

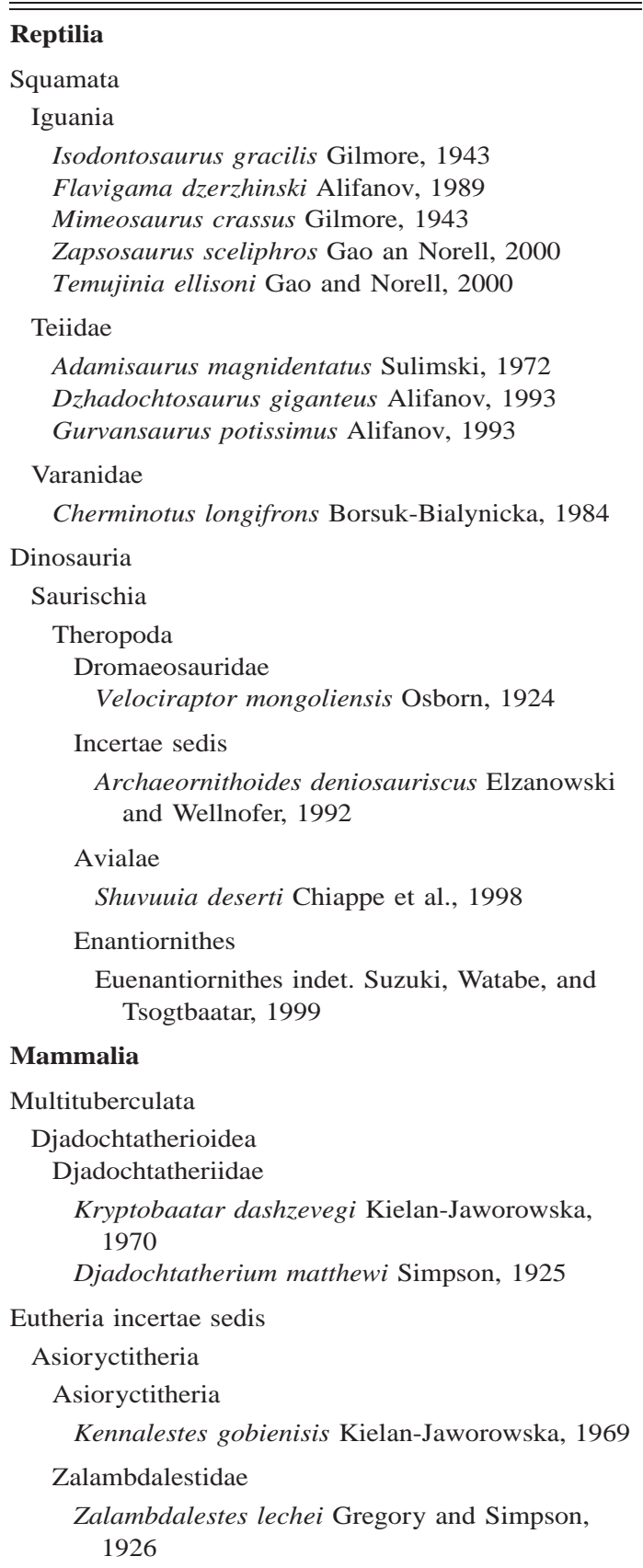

\section{MAGNETOSTRATIGRAPHIC IMPLICATIONS FOR THE AGE OF THE TUGRUGYIN SHIREH FAUNA}

As noted in a previous section on the sequence at Alag Teer, the basal, light gray sands of the Tugrugyin Member in Units 4 and 5 are reversed. This polarity corresponds to the uppermost beds of the Bayn Dzak Member at the Flaming Cliffs, the mudstone at Khren Tsav, and the mudstone at Tsonzh. If the zones of reversed polarity at these localities correlate, it means that these units must be younger than Chron $34 n$ - the upper boundary of which represents the boundary between the Santonian and the Campanian at about 83.5 Ma (Gradstein et al., 1995). The quick stratigraphic succession of normal and reversed magnetozones in the Flaming Cliffs section suggests, but does not clearly establish, that the sediments were deposited during the rapid sequence of polarity changes in the late part of the Campanian incorporating the end of Chron 33 and Chron 32 between about 75 and 71 Ma (Gradstein et al., 1995).

\section{CONCLUSIONS}

Two new members can be broken out within the Djadokhta Formation based on exposures at Bayn Dzak, Tugruyin Shireh, Tsonzh, and Alag Teer. The lower member, named the Bayn Dzak, is composed of moderate reddish orange, crossbedded, and structureless sandstones, with subordinate deposits of brown siltstone and mudstone. The crossbedded and structureless sandstones respectively represent eolian dunes and fluvial deposits or sandslides that occurred on the dune faces. The mudstone and siltstone represents an interdune facies deposited by fluvial action. The upper member is named the Tugrugyin Member and consists of very pale orange to light gray sands that also represent a crossbedded dune facies and a structureless sandslide facies. Transitional mudstone and siltstone units separate the two members at Tsonzh and Alag Teer.

Vertebrate fossils occur almost exclusively in the structureless sandstones of both members. Although the fauna from the Bayn Dzak Member is somewhat older than that from the Tugrugyin Member, based on the superpositional relationships, many of the 


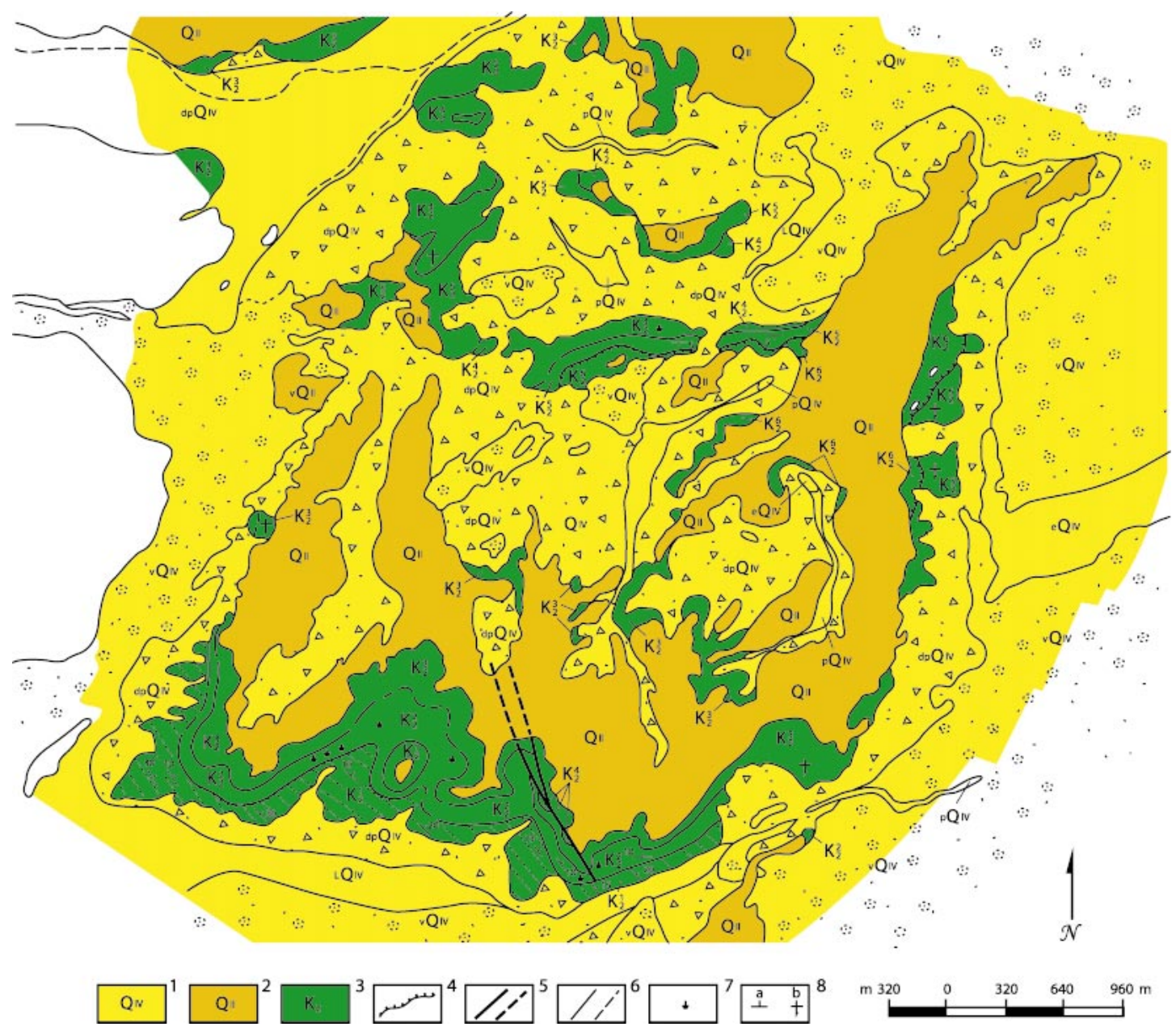

Map 3. Geologic map of major lithologic units at Tugrugyin Shireh. Compiled by T. Dulam in July 1998. 1. Holocene: eolian sands, vQiv; deluvid sands, dpQiv; lake clay and sand, lQiv; proluvial sand and debris, pQiv. 2. Pleistocene: deluvial-proluvial sand and debris, partly with limy matrix. 3. Upper Cretaceous: Tugrugyin Member: K1/2 yellowish, weakly lithified, small-medium-grained sand. White sand slice. K2/2 unlithified, yellowish sands containing concretionary white sandstone nodules. K3/2 less concretionary white sand. K5/2 white sand. K6/2 white sand. Bayn Dzak Member: K4/2 red sand with light spots. 4. Unlithified, white sand, rich with mud craters, footprints, and less sandstone nodules. 5. Faults: a: known; b: inferred. 6. Geologic boundaries: a: clear; b: unclear. 7. Points of observation of fossil bone. 8. Orientation of bedrock: a: inclined; b: horizontal.

same taxa have been collected from both members. It is not yet possible to estimate precisely the temporal difference separating the faunas from the two members.

New magnetostratigraphic samples throughout the Bayn Dzak Member and at the base of the Tugrugyin Member document the presence of a sequence of normal and reversed magnetozones. Previous biochronologic age estimates taken in conjunction with this new magnetostratigraphic data suggest that the fossiliferous sediments of the Djadokhta Formation were most likely deposited during the quick succession of normal and reversed intervals in the late Campanian between 71 and $75 \mathrm{Ma}$.

\section{ACKNOWLEDGMENTS}

The authors wish to thank the Mongolian Academy of Sciences as well as the field 
crews from the American Museum of Natural History. We also wish to thank Christopher Bennett, Alexander Kellner, and Zofia Kielan-Jaworowska for their extensive reviews of this manuscript, without implying that they concur with all the statements and conclusions presented herein. Financial support for this study was provided by the Frick Endowment to the Division of Paleontology at the American Museum of Natural History, the InfoQuest Foundation, the Ann and Gordon Getty Foundation, and the Charlotte and Walter Kohler Charitable Trust.

\section{REFERENCES}

Alifanov, V.R. 2000. The fossil record of the Cretaceous lizards from Mongolia. In M.J. Benton, M.A. Shishkin, E.N. Kurochkin, and D.M. Unwin (editors), The age of dinosaurs in Russia and Mongolia: 368-389. Cambridge: Cambridge University Press.

Andrews, R.C. 1932. The new conquest of Central Asia, natural history of Central Asia, I. New York: American Museum of Natural History, $687 \mathrm{pp}$.

Averianov, A.O. 1997. New Late Cretaceous mammals of southern Kazakhstan. Acta Palaeontologica Polonica 42: 243-256.

Belyaeva, Y.I., B.A. Trofimov, and U.Y. Reshetov. 1974. Basic stages in the evolution of the late Mesozoic-Paleogene mammals of Central Asia. In N.N. Kramerenko (editor), Mesozoic and Cenozoic faunas and biostratigraphy of Mongolia. The Joint Soviet-Mongolian Paleontological Expedition Transaction 1: 19-45. Moscow: Science Press.

Benton, M.J. 2000. Stratigraphic units in the Permo-Mesozoic of Russia and Middle Asia. In M.J. Benton, M.A. Shishkin, E.N. Kurochkin, and D.M. Unwin (editors), The age of dinosaurs in Russia and Mongolia: xx-xxi. Cambridge: Cambridge University Press.

Benton, M.J., M.A. Shishkin, E.N. Kurochkin, and D.M. Unwin. 2000. The age of dinosaurs in Russia and Mongolia. Cambridge: Cambridge University Press, xxix +696 pp.

Berkey, C.P., and F.K. Morris. 1927. Geology of Central Asia, natural history of Central Asia, II. New York: American Museum of Natural History, 475 pp.

Borsuk-Bialynicka, M. 1984. Anguimorphans and related lizards from the Late Cretaceous of the Gobi Desert, Mongolia. In Z. Kielan-Jaworowska (editor), Results of the Polish-Mongolian Palaeontological Expeditions, Part X. Palaeontologia Polonica 46: 5-105.
Borsuk-Bialynicka, M. 1991a. Cretaceous lizard occurrences in Mongolia. Cretaceous Research 12: 607-608.

Borsuk-Bialynicka, M. 1991b. Questions and controversies about saurian phylogeny, Mongolian perspective. In Z. Kielan-Jaworowska, N. Heintz, and H.A. Nakrem (editors), Fifth Symposium on Mesozoic Terrestrial Ecosystems and Biota, Oslo: 9-10.

Chiappe, L.M., M.A. Norell, and J.M. Clark. 1998. The skull of a relative of the stem-group bird Mononykus. Nature 392: 275-278.

Dingus, L., D.B. Loope, D. Dashzeveg, C.C. Swisher III, C. Minjin, M.J. Novacek, and M.A. Norell. In review. The geology of Ukhaa Tolgod (Djadokhta Formation, Upper Cretaceous, Nemegt Basin, Mongolia). American Museum Novitates.

Eberth, D.A. 1993. Depositional environments and facies transitions of dinosaur-bearing Upper Cretaceous redbeds at Bayan Mandahu (Inner Mongolia, People's Republic of China). Canadian Journal of Earth Sciences. 30: 21962213.

Efremov, I.A. 1949. Preliminary results of the work of the first Mongolian Paleontological Expedition of the Academy of Sciences USSR, 1946. Trudy Mongolskoy Komissii AN SSSR 38: 8-27.

Efremov, I.A. 1954. Paleontological Expedition of the Mongolian People's Republic (Preliminary results of 1946, 1948 and 1949 expeditions). Trudy Mongolskoy Komissii AN SSSR 59: 322.

Elzanowski, A., and P. Wellnhofer. 1992. A new link between theropods and birds from the Cretaceous of Mongolia. Nature 359: 821-823.

Fastovsky, D.E., D. Badamgarav, H. Ishimoto, M. Watabe, and D.B. Weishampel. 1997. The paleoenvironments of Tugrikin-Shireh (Gobi Desert, Mongolia) and aspects of the taphonomy and paleoecology of Protoceratops (Dinosauria: Ornithischia). Palaios 12: 59-70.

Fox, R.C. 1978. Upper Cretaceous terrestrial vertebrate stratigraphy of the Gobi Desert (Mongolian People's Republic) and western North America. Geological Association of Canada Special Paper 18: 571-594.

Gao, K., and M.A. Norell. 2000. Taxonomic composition and systematics of Late Cretaceous assemblages from Ukhaa Tolgod and Adjacent localities, Mongolian Gobi Desert. Bulletin of the American Museum of Natural History 249: 1118.

Gilmore, C.W. 1931. Fossil turtles of Mongolia. Bulletin of the American Museum of Natural History 59: 213-257.

Gradstein, F.M., F.P. Agterberg, J.G. Ogg, J. Har- 
denbol, P.V. Veen, J. Thierry, and Z. Huang. 1995. A Triassic, Jurassic and Cretaceous time scale. In W.A. Berggren, D.V. Kent, and J. Hardenbol (editors), Geochronology, timescales and global stratigraphic correlation. Society of Economic Paleontologists and Mineralogists Special Publication 54: 95-126.

Gradziński, R. 1970. Sedimentation of dinosaurbearing Upper Cretaceous deposits of the $\mathrm{Ne}$ megt Basin, Gobi Desert. In Z. Kielan-Jaworowska (editor), Results of the Polish-Mongolian Palaeontological Expeditions, Part II. Palaeontologia Polonica 21: 147-229.

Gradziński, R., and T. Jerzykiewicz. 1972. Additional geographical and geological data from the Polish-Mongolian Palaeontological Expeditions. In Z. Kielan-Jaworowska (editor), Results of the Polish-Mongolian Palaeontological Expeditions, Part IV. Palaeontologia Polonica 25: $17-30$.

Gradziński, R., and T. Jerzykiewicz. 1974. Dinosaur- and mammal-bearing aeolian and associated deposits of the Upper Cretaceous in the Gobi Desert (Mongolia). Sedimentary Geology 12: 249-278.

Gradziński, R., J. Kaźimierczak, and J. Lefeld. 1969. Geographical and geological data from the Polish-Mongolian Palaeontological Expedition. In Z. Kielan-Jaworowska (editor), Results of the Polish-Mongolian Palaeontological Expeditions, Part I. Paleontologia Polonica 19: 33-82.

Gradziński, R., Z. Kielan-Jaworowska, and T. Maryańska. 1977. Upper Cretaceous Djadokhta, Barun Goyot and Nemegt Formations of Mongolia, including remarks on previous subdivisions. Acta Geologica Polonica 27: 281-318.

Granger, W., and W.K. Gregory. 1923. Protoceratops andrewsi, a pre-ceratopsian dinosaur from Mongolia. American Museum Novitates 72: 1-9.

Gregory, W.K., and G.G. Simpson. 1926. Cretaceous mammal skulls from Mongolia. American Museum Novitates 225: 1-20.

Ishii, K., M. Watabe, S. Suzuki, S. Ishigaki, R. Barsbold, and K. Tsogtbaatar. 2000. Results of the Hayashibara Museum of Natural SciencesMongolian Academy of Sciences Mongolian Paleontological Center Joint Paleontological Expedition. Hayashibara Museum of Natural Sciences Research Bulletin 1: 1-137.

Ishii, K., M. Watabe, S. Suzuki, S. Ishigaki, R. Barsbold, and K. Tsogtbaatar. 2004. Results of the Hayashibara Museum of Natural SciencesMongolian Academy of Sciences Mongolian Paleontological Center Joint Paleontological Expedition. Hayashibara Museum of Natural Sciences Research Bulletin 2: 1-134.
Jerzykiewicz, T. 2000. Lithostratigraphy and sedimentary settings of the Cretaceous dinosaur beds of Mongolia. In M.J. Benton, M.A. Shishkin, E.N. Kurochkin, and D.M. Unwin (editors), The age of dinosaurs in Russia and Mongolia: 279-296. Cambridge: Cambridge University Press.

Jerzykiewicz, T., and D.A. Russell. 1991. Later Mesozoic stratigraphy and vertebrates of the Gobi Basin. Cretaceous Research 12: 345-377.

Jerzykiewicz, T., E.H. Koster, and J.-J. Zengh. 1993. Djadokhta Formation correlative strata in Chinese Inner Mongolia: an overview of the stratigraphy, sedimentary geology, and paleontology and comparisons with the type locality in the pre-Altai Gobi. Canadian Journal of Earth Sciences 30: 2180-2195.

Kielan-Jaworowska, Z. 1969. Preliminary data on the Upper Cretaceous eutherian mammals from Bayn Dzak, Gobi Desert. In Z. Kielan-Jaworowska (editor), Results of the Polish-Mongolian Palaeontolgical Expeditions, Part 1. Palaeontologia Polonica 19: 171-191.

Kielan-Jaworowska, Z. 1970. New Upper Cretaceous multituberculate genera from Bayn Dzak, Gobi Desert. In Z. Kielan-Jaworowska (editor), Results of the Polish-Mongolian Palaeontological Expeditions, Part II. Palaeontologia Polonica 21: 35-49.

Kielan-Jaworowska, Z. 1974. Multituberculate succession in the late Cretaceous of the Gobi Desert (Mongolia). In Z. Kielan Jaworowska (editor), Results of the Polish-Mongolian Palaeontological Expeditions, Part V. Palaeontologia Polonica 30: 23-44.

Kielan-Jaworowska, Z. 1975. Evolution of the therian mammals in the Late Cretaceous of Asia. Part I. Deltatheridiidae. In Z. Kielan-Jaworowska (editor), Results of the Polish-Mongolian Palaeontological Expeditions, Part VI. Palaeontologia Polonica 33: 103-132.

Kielan-Jaworowska, Z. 1984. Evolution of the therian mammals in the Late Cretaceous of Asia. Part VII. Synopsis. In Z. Kielan-Jaworowska (editor), Results of the Polish-Mongolian Palaeontological Expeditions, Part X. Palaeontologia Polonica 46: 173-183.

Kielan-Jaworowska, Z., and R. Barsbold. 1972. Narrative of the Polish-Mongolian Palaeontological Expeditions 1967-1971. In: Z. KielanJaworowska (editor), Results of the PolishMongolian Palaeontological Expeditions, Part IV. Palaeontologia Polonica 27: 5-13.

Kielan-Jaworowska, Z., and N. Dovchin. 1969. Narrative of Polish-Mongolian Expedition 1963-1965. In Z. Kielan-Jaworowska (editor), Results of the Polish-Mongolian Palaeontolog- 
ical Expeditions, Part I. Palaeontologia Polonica 19: 7-32.

Kielan-Jaworowska, Z., and J.H. Hurum. 1997. Djadochtatheria- a new suborder of multituberculate mammals. Acta Palaeontologia Polonica 42: 201-242.

Kielan-Jaworowska, Z., and J.H. Hurum. 2001. Phylogeny and systematics of multituberculate mammals. Palaeontology 44: 389-429.

Kielan-Jaworowska, Z., J.H. Hurum, and D. Badamgarav. 2003. Multituberculate mammal Kryptobaatar and the distribution of mammals in the Upper Cretaceous rocks of the Gobi Desert. Acta Palaeontologica Polonica 49: 161166.

Kielan-Jaworowska, Z., M.J. Novacek, B.A. Trofimov, and D. Dashzeveg. 2000. Mammals from the Mesozoic of Mongolia. In M.J. Benton, M.A. Shishkin, E.N. Kurochkin, and D.M. Unwin (editors), The age of dinosaurs in Russia and Mongolia: 573-652. Cambridge: Cambridge University Press.

Kurochkin, E.N., and R. Barsbold. 2000. The Russian-Mongolian expeditions and research in vertebrate paleontology. In M.J. Benton, M.A. Shishkin, E.N. Kurochkin, and D.M. Unwin (editors), The age of dinosaurs in Russia and Mongolia: 235-255. Cambridge: Cambridge University Press.

Lefeld, J. 1965. The age of mammal containing beds at Bayn Dzak, northern Gobi Desert. Bulletin de l'Académie polonaise des sciences C1, III, Série des sciences géologiques et. géographiques 13: 81-83.

Lefeld, J. 1971. Geology of the Djadokhta Formation at Bayn Dzak (Mongolia). In Z. KielanJaworowska (editor), Results of the PolishMongolian Palaeontological Expeditions, Part III. Palaeontologia Polonica 25: 101-127.

Lillegraven, J.A., and M.C. McKenna. 1986. Fossil mammals from the "Mesaverde" Formation/ Late "Cretaceous North American Land-Mammal Ages". American Museum Novitates 2840: $1-68$.

Loope, D.B., L. Dingus, C.C. Swisher III, and C. Minjin. 1998. Life and death in a late Cretaceous dune field, Nemegt basin, Mongolia. Geology 26: 27-30.

Loope, D.B., and L. Dingus. 1999. Mud-filled Ophiomorpha from the Upper Cretaceous continental redbeds of southern Mongolia: an ichnologic clue to the origin of detrital grain coatings. Palaios 14: 451-458.

Maleev, E.A. 1952. A new family of armoured dinosaurs from the Upper Cretaceous deposits. Doklady Akademii Nauk SSSR 87: 131-134.

Maleev, E.A. 1954. Armoured dinosaurs from the Upper Cretaceous of Mongolia (the Syrmo- sauridae Family). Trudy Paleontologicheskogo Instituta Akademii Nauk SSSR 48: 142-170.

Maryańska, T. 1971. New data of the skull of Pinacosaurus grangeri (Ankylosauria). In Z. Kielan-Jaworowska (editor), Results of the PolishMongolian Palaeontological Expeditions, Part III. Palaeontologia Polonica 25: 45-53.

Maryańska, T. 1977. Ankylosauridae (Dinosauria) from Mongolia. In Z. Kielan-Jaworowska (editor), Results of the Polish-Mongolian Palaeontological Expeditions, Part VII. Palaeontologia Polonica 37: 85-151.

Maryańska, T., and H. Osmólska. 1975. Protoceartopsidae (Dinosauria) from Asia. In Z. Kielan-Jaworowska (editor), Results of the PolishMongolian Palaeontological Expeditions, Part VI. Palaeontologia Polonica 33: 133-181.

McKenna, M.C. 1969. The origin and early differentiation of the therian mammals. Annals of the New York Academy of Science 167: 217240.

Mikhailov, K.E. 1994. Theropod and protoceratopsian dinosaur eggs from the Cretaceous of Mongolia and Kazakhstan. Paleontological Journal 28(2): 101-120.

Mikhailov, K.E. 1995. Systematic, faunistic and stratigraphic diversity of Cretaceous eggs in Mongolia: comparison with China. In A. Sun and Y. Wang (editors), Sixth Symposium on Mesozoic Terrestrial Ecosystems and Biota Short Papers, 165-168. Beijing: China Ocean Press.

Mikhailov, K.E. 1996. New genera of fossil eggs from the Late Cretaceous of Mongolia. Paleontological Journal 30(2): 246-248.

Mikhailov, K.E., K. Sabath, and S. Kurzanov. 1994. Eggs and nests from the Cretaceous of Mongolia. In K. Carpenter, K.F. Hirsch, and J.R. Horner (editors), Dinosaur eggs and babies: 88-115. New York: Cambridge University Press.

Mook, C.C. 1924. A new crocodilian from Mongolia. American Museum Novitates 117: 1-5.

Morris, F.K. 1936. Central Asia in Cretaceous time. Geological Society of America Bulletin 47: 1477-1534.

Nikoloff, I., and F. Huene. 1966. Neue Vertebratenfunde in der Wuste Gobi. Neues Jahrbuch der Geologie und Paleontologie 11: 691-694.

Norell, M.A., J.M. Clark, D. Dashzeveg, R. Barsbold, L.M. Chiappe, A.R. Davidson, M.C. McKenna, A. Perle, and M.J. Novacek. 1994. A theropod dinosaur embryo and the affinities of the Flaming Cliffs dinosaur eggs. Science 226: 779-782.

Norell, M.A., and P.J. Makovicky. 1997. Important features of the dromaeosaur skeleton: in- 
formation from a new specimen. American $\mathrm{Mu}$ seum Novitates 3215: 1-28.

Novacek, M.J., M.A. Norell, M.C. McKenna, and J. Clark. 1994. Fossils of the Flaming Cliffs. Scientific American, December: 60-69.

Novacek, M.J., G.W. Rougier, J.R. Wible, M.C. McKenna, D. Dashzeveg, and I. Horovitz. 1997. Epipubic bones in eutherian mammals from the Late Cretaceous of Mongolia. Nature 389: 483-486.

Novojilov, N.I. 1954. Localities of mammals of Upper Paleocene and Lower Eocene in Mongolia. Trudy Mongolskoy Komissii AN SSSR 59: 33-46.

Osborn, H.F. 1924. Three new Theropoda, Protoceratops zone, Central Mongolia. American Museum Novitates 144: 1-12.

Osmólska, H. 1972. Preliminary note on a crocodilian from the Upper Cretaceous of Mongolia. In Z. Kielan-Jaworowska (editor), Results of the Polish-Mongolian Palaeontological Expeditions, Part III. Palaeontologia Polonica 27: 43-47.

Osmólska, H. 1976. New light on the skull anatomy and systematic position of Oviraptor. Nature 262: 683-684.

Osmólska, H. 1980. The Late Cretaceous vertebrate assemblages of the Gobi Desert, Mongolia. Memoirs de la Societé Geologique de France 139: 145-150.

Osmólska, H. 1993. Were the Mongolian "fighting dinosaurs" really fighting? Review de Paléobiologie Special Volume 7: 161-162.

Rougier, G.W., M.J. Novacek, and D. Dashzeveg. 1997. A new multituberculate from the Late Cretaceous locality Ukhaa Tolgod, Mongolia. Considerations on multituberculate relationships. American Museum Novitates 3193: 126.

Rougier, G.W., J.R. Wible, and M.J. Novacek. 1996. Middle-ear ossicles of the multituberculate Kryptobaatar from the Mongolian Late Cretaceous: implication for mammaliamorph relationships and the evolution of the auditory apparatus. American Museum Novitates 3187: $1-45$.

Rougier, G.W., J.R. Wible, and M.J. Novacek. 1998. Implications of Deltatheridium specimens for early marsupial history. Nature 396: 459-463.

Rozhdestvensky, A.K. 1971. Study of dinosaurs and their role in continental Mesozoic subdivision. In N.S. Zaitsev (editor), Mesozoic and Cenozoic fauna of Western Mongolia. The Joint Soviet-Mongolian Scientific Research Geological Expedition Transactions 3: 21-32.
Sabath, K. 1991. Upper Cretaceous amniote eggs from the Gobi Desert. Acta Palaeontologia Polonica 36(1): 151-192

Shuvalov, V.F. 2000. The Cretaceous stratigraphy and palaeobiogeography of Mongolia. In M.J. Benton, M.A. Shishkin, E.N. Kurochkin, and D.M. Unwin (editors), The age of dinosaurs in Russia and Mongolia: 256-278. Cambridge: Cambridge University Press.

Smith, T., D.-Y. Guo, and Y. Sun. 2001. A new species of Kryptobaatar (Multituberculata): the first Late Cretaceous mammal from Inner Mongolia (P. R. China). Bulletin de l'Institut Royal des Sciences Naturelles de Belgique Sciences de la Terre 71(suppl.): 29-50.

Sulimski, A. 1975. Macrocephalosauridae and Polyglyphanodontidae (Sauria) from the Late Cretaceous of Mongolia. In Z. Kielan-Jaworowska (editor), Results of the Polish-Mongolian Palaeontological Expeditions, Part IV. Palaeontologica Polonica 33: 25-102.

Suzuki, S., M. Watabe, and K. Tsogtbaatar. 1999. A new enantiornithine bird from the upper Cretaceous Djadokhta formation of Gobi Desert, Mongolia. Journal of Vertebrate Paleontology 3(suppl. 19): 79A-80A.

Tereschenko, V.S., and V.R. Alifanov. 2003. Bainoceratops efremovi, a new protoceratopsid dinosaur (Protoceratopsidae, Neoceratopsia) from the Bain-Dzak Locality (South Mongolia). Paleontological Journal 37(3): 293-302.

Watabe, M., and S. Suzuki. 2000. Cretaceous fossil localities and a list of fossils collected by the Hayashibara Museum of Natural Sciences and Mongolian Paleontological Joint Paleontological Expedition (JMJPE from 1993 through 1998). In K. M. Ishii, M. Watabe, S. Suzuki, S. Ishigaki, R. Barsbold, and K. Tsogtbaatar (editors), Results of the Hayashibara Museum of Natural Sciences-Mongolian Academy of Sciences Mongolian Paleontological Center Joint Paleontological Expedition. Hayashibara $\mathrm{Mu}-$ seum of Natural Sciences Research Bulletin 1: 99-108.

Wible, J.R., and G.W. Rougier. 2000. The cranial anatomy of Kryptobaatar dashzevegi (Mammalia, Multituberculata), and its bearing on the evolution of mammalian characters. Bulletin of the American Museum of Natural History 247: $1-124$.

Yang, X., T. Liu, and H. Xiao. 2003. Evolution of megadunes and lakes in the Badain Jaran Desert, Inner Mongolia, China during the last 31,000 years. Quaternary International 104: 99-112. 
Complete lists of all issues of the Novitates and the Bulletin are available at World Wide Web site http://library.amnh.org/pubs. Inquire about ordering printed copies via e-mail from scipubs@amnh.org or via standard mail from: American Museum of Natural History, LibraryScientific Publications, Central Park West at 79th St., New York, NY 10024. TEL: (212) 7695545. FAX: (212) 769-5009.

(2) This paper meets the requirements of ANSI/NISO Z39.48-1992 (Permanence of Paper). 